\title{
4'-C-Methoxy-2'-Deoxy-2'-Fluoro Modified Ribonucleotides Improve Metabolic Stability and Elicit Efficient RNAi-Mediated Gene Silencing
}

Elise Malek-Adamian ${ }^{1 \$}$, Dale C. Guenther ${ }^{3 \$}$, Shigeo Matsuda ${ }^{3}$, Saúl Martínez-Montero ${ }^{1}$, Ivan Zlatev $^{3}$, Joel Harp, ${ }^{2}$ Mihai Burai Patrascu ${ }^{1}$, Donald J. Foster ${ }^{3}$, Johans Fakhoury ${ }^{1}$, Lydia Perkins ${ }^{3}$, Nicolas Moitessier ${ }^{1}$, Rajar M. Manoharan ${ }^{3}$, Nate Taneja ${ }^{3}$, Anna Bisbe ${ }^{3}$, Klaus Charisse ${ }^{3}$, Martin Maier $^{3}$, Kallanthottathil G. Rajeev ${ }^{3}$, Martin Egli ${ }^{2}$, Muthiah Manoharan ${ }^{* 3}$, and Masad J. Damha*1

${ }^{1}$ Department of Chemistry, McGill University, 801 Sherbrooke Street West, Montreal, QC, Canada H3A 0B8.

${ }^{2}$ Department of Biochemistry, School of Medicine, Vanderbilt University, Nashville, TN 37232, USA.

${ }^{3}$ Alnylam Pharmaceuticals, 300 Third Street, Cambridge, MA 02142, USA.

$\$$ contributed equally to this work

\begin{abstract}
.
We designed novel 4'-modified 2'-deoxy-2'-fluorouridine (2'-F U) analogues with the aim to improve nuclease resistance and potency of therapeutic siRNAs by introducing $4^{\prime}-C$-methoxy $\left(4^{\prime}-\mathrm{OMe}\right)$ as the alpha $\left(\mathrm{C}^{\prime} \alpha\right)$ or beta $\left(\mathrm{C}^{\prime} \beta\right)$ epimers. The $\mathrm{C} 4^{\prime} \alpha$ epimer was synthesized by a stereoselective route in six steps; however, both $\alpha$ and $\beta$ epimers could be obtained by a nonstereoselective approach starting from $2^{\prime}-\mathrm{F}$ U. ${ }^{1} \mathrm{H}-\mathrm{NMR}$ analysis and computational investigation of the $\alpha$-epimer revealed that the 4'-OMe imparts a conformational bias towards the North-East sugar pucker, due to intramolecular hydrogen bonding and hyperconjugation effects. The $\alpha-$ epimer generally conceded similar thermal stability as unmodified nucleotides, whereas the $\beta$ epimer led to significant destabilization. Both 4'-OMe epimers conferred increased nuclease resistance, which can be explained by the close proximity between 4'-OMe substituent and the vicinal 5'- and 3'-phosphate group, as seen in the X-ray crystal structure of modified RNA. siRNAs containing several $\mathrm{C}^{\prime} \alpha$-epimer monomers in the sense or antisense strands triggered RNAi-mediated gene silencing with efficiencies comparable to that of 2'-F U.
\end{abstract}




\section{Introduction.}

RNA interference (RNAi) is an endogenous post-transcriptional regulatory gene silencing pathway that has been successfully harnessed for silencing potentially any gene of interest with the use of small interfering RNA (siRNA). ${ }^{1}$ RNAi-mediated gene silencing has gained considerable attention due to the enormous therapeutic potential for treating disease in humans. ${ }^{2-}$ ${ }^{4}$ siRNA requires chemical modifications to increase cellular uptake, metabolic stability, evade the innate immune response, confer beneficial pharmacokinetic and pharmacodynamic profiles, and yet still be compatible with the RNAi pathway. ${ }^{5}$

Exploration of chemical modifications to the ribose moiety of RNA has been the target of extensive efforts aimed to enhance the binding, stability and functional properties of nucleic acid analogs in antisense, RNAi and aptamer applications. Among the possible modification sites, C2' and $\mathrm{O} 2$ ' figure prominently, as $2^{\prime}-\mathrm{C}$ - and 2'-O- modified analogs allow modulation of sugar pucker, polarity, hydration and binding affinity to the interactions with both nucleic acid and protein targets. ${ }^{6}$ One of the most prominent chemical modifications in nucleic acid based applications is $2^{\prime}$-deoxy-2'-fluoro (2'-F) ribonucleotides because of its RNA-like sugar pucker $\left(\mathrm{C} 3\right.$ '-endo) that increases binding affinity to target $\mathrm{RNA},{ }^{7,8,9}$ endonuclease resistance, ${ }^{10,11}$ decreases immune stimulation, ${ }^{12,13}$ and improves siRNA activity. ${ }^{14,15}$ The preferred C3'-endo sugar pucker is driven by the electronegative $2^{\prime}-\mathrm{C} \alpha-\mathrm{F}$, which has favorable gauche interactions. ${ }^{16}$

Substitution at $\mathrm{C}^{\prime}$ ' also alters the stereoelectronics and subsequently the sugar conformation. 2'Deoxy-4'-C-fluoro ribonucleosides were previously investigated, ${ }^{17-20}$ however rapid depurination was observed in aqueous solution and impeded evaluation in oligonucleotides. 4'-Substitution with less electronegative substituents such as $4^{\prime}$-methoxy (4'-OMe), overcame the acid instability of the 2'-deoxynucleoside, while still influencing the sugar conformation. ${ }^{21}$ Petrová et al. recently reported the synthesis of 4'-C-OMe-2'-deoxynucleosides and their incorporation into 9mer oligomers, where their binding affinity and acid stability was shown to be enhanced with a strong tendency for RNA-selective hybridization. ${ }^{22}$ Also recently, chemically stable 2'-deoxy-2'fluoro-4'- $C$-fluoro pyrimidine nucleotides $\left(2^{\prime}, 4^{\prime}-\mathrm{diF}\right)$ were reported. ${ }^{16,23,24}$ The two fluoro substituents essentially "lock" the sugar in a single North-type conformation, which has previously only been accomplished using a bicyclic scaffold such as locked nucleic acid (LNA), ${ }^{25-27}$ tricyclo-DNA, ${ }^{28}$ or Northern-methanocarba-cyclic thymidine. ${ }^{29,30}$ LNA dramatically 
improved binding affinity due to the increased pre-organization within the single strand, which reduces the entropic penalty for duplex formation. ${ }^{31}$ Even though $2^{\prime}, 4^{\prime}-\mathrm{diF} \mathrm{U}$ is also conformationally locked, it does not significantly alter the thermal stability compared to unmodified RNA duplexes. ${ }^{24}$

We rationalized that the 2'-F and 4'-OMe di-substituted nucleotides will maintain a strong bias towards a North-type sugar conformation, supporting an A-form duplex and displaying favorable properties for use in RNAi applications. Additionally, placement of the bulky 4'-OMe group may also impart higher resistance to nuclease degradation by sterically blocking access to the two vicinal phosphodiester linkages. In conjunction, these modifications are hypothesized to display favorable properties for RNAi applications.

In the present study, we describe the synthesis and conformational analysis of both epimers of 2'deoxy-2'-fluoro-4'- $C$-methoxy uridine (2'-F-4'- $C \alpha$-OMe U, 6, and 2'-F-4'-C $C \beta$-OMe U, 18; Figure 1) by NMR, as well as computational analysis of the $C \alpha$-epimer. We evaluated their impact on duplex thermal stability, protection against exonuclease degradation, and used the crystal structure of self-complementary RNA duplexes containing 2'-F-4'-Ca-OMe $\mathrm{U}$ to better understand the effect of these modifications on nucleic acid structure and function. Finally, we evaluated the in vitro gene silencing efficiency of siRNA containing single or multiple incorporations into either the sense or antisense strands.

A

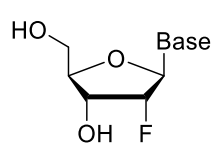

2'-F U

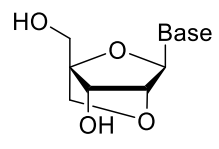

LNA

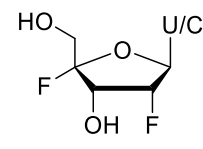

$2^{\prime}, 4^{\prime}-\mathrm{diF}$

B

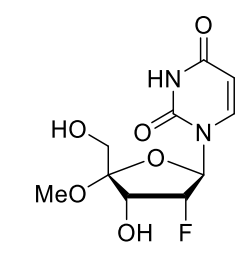

4'-C $\alpha-O M e-2 '-F ~ U ~(6)$

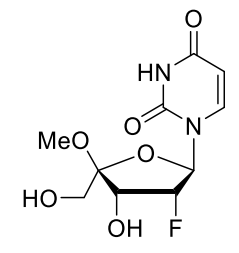

4'-Cß-OMe-2'-F U (18)

Figure 1. (A) Selected literature examples of 2'- and 4'-modified nucleosides: 2'-F, LNA, and $2^{\prime}, 4^{\prime}-\mathrm{diF}$. (B) Structures of 2'-F-4'-C $\alpha$-OMe U and 2'-F-4'- $C \beta$-OMe U presented herein. 


\section{Synthesis.}

The syntheses of 2'-F-4'-OMe U monomers were accomplished following two different routes: a stereoselective (Scheme 1) and a non-stereoselective (Scheme 2), affording both the $\mathrm{C}^{\prime}{ }^{\prime} \alpha$ - and $\mathrm{C} 4$ ' $\beta$-epimers. The stereoselective introduction of methoxy group at the $\mathrm{C} 4$ ' $\alpha$-position was inspired by previously published procedures. ${ }^{32} 4^{\prime}, 5^{\prime}$-Olefinic compound 2 was prepared by $5^{\prime}$ iodination of $2^{\prime}-\mathrm{F} \quad \mathrm{U}$ followed by an elimination reaction facilitated by 1,8 diazabicyclo(5.4.0)undec-7-ene (DBU). Compound 3 was prepared stereoselectively by suspending 2 in methanol and $\mathrm{PbCO}_{3}$ followed by slow addition of an iodine solution in methanol at $0{ }^{\circ} \mathrm{C} .{ }^{33}$ The $3^{\prime}-\mathrm{OH}$ of compound 3 was benzoylated using $\mathrm{BzCl}$ in pyridine to yield compound 4. Displacement of the 5'-iodine of compound 4 was achieved with $m$ CPBA in watersaturated dichloromethane with concomitant migration of the benzoyl group to the $5^{\prime}$ position to afford protected nucleoside 5. ${ }^{16,34}$ Deprotection of the $5^{\prime}$ - $O$-benzoyl group in $2 \mathrm{M}$ methanolic ammonia afforded the free nucleoside $6\left(2^{\prime}-\mathrm{F}-4^{\prime}-\mathrm{C} \alpha-\mathrm{OMe} \mathrm{U}\right)$ in high yield. For incorporation into ONs, the nucleoside 6 was converted into the corresponding 5'-O-dimethoxytrityl-3'-Ophosphoramidite building block 8 via standard procedures. ${ }^{35}$

Scheme 1. Stereoselective synthesis of 2'-F-4'-Ca-OMe U 6 and its corresponding phosphoramidite $\mathbf{8}^{a}$
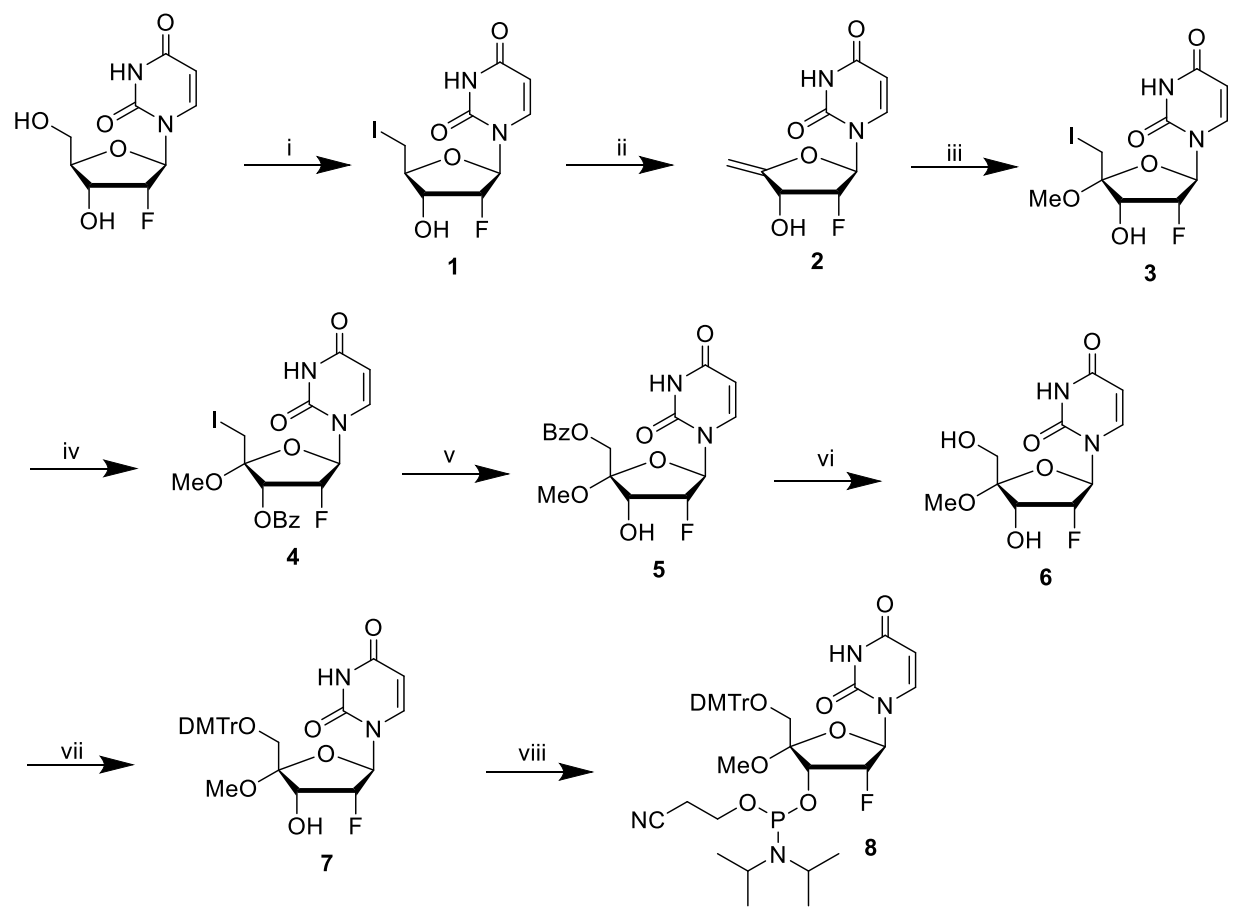
aReagents and conditions: (i) $\mathrm{I}_{2}, \mathrm{PPh}_{3} / \mathrm{MeCN}$, pyridine, rt, $48 \mathrm{~h}, 89 \%$; (ii) DBU/THF, rt, overnight, $83 \%$ (iii) $\mathrm{PbCO}_{3}, \mathrm{I}_{2} / \mathrm{MeOH}, 0{ }^{\circ} \mathrm{C}$, overnight, $67 \%$ (iv) $\mathrm{BzCl} /$ pyridine, rt, overnight, $86 \%$ (v) $m \mathrm{CPBA} / \mathrm{DCM}, \mathrm{H}_{2} \mathrm{O}, 40{ }^{\circ} \mathrm{C}, 6 \mathrm{~h}, 62 \%$ (vi) $2 \mathrm{M} \mathrm{NH}_{3} / \mathrm{MeOH}, \mathrm{rt}$, overnight, $97 \%$ (vii) $\mathrm{DMTr}-\mathrm{Cl} /$ pyridine, $45^{\circ} \mathrm{C}, 3 \mathrm{~h}, 78 \%$ (viii) 2-cyanoethyl $N, N$-diisopropylchlorophosphoramidite, DIPEA/THF, rt, 7 h, $49 \%$.

The non-stereoselective syntheses of the $\mathrm{C} \alpha$ - and $\mathrm{C} \beta$-epimers of 2'-F-4'-OMe $\mathrm{U}$ were accomplished using well-established chemistry, namely electrophilic addition to $4^{\prime}, 5^{\prime}$-unsaturated nucleosides (Scheme 2). ${ }^{34,36}$ Briefly, TBS-protected nucleoside 9 was treated with $m$ CPBA in methanol to afford a 3:1 separable mixture of the $4^{\prime}-C \alpha-O M e$ epimer 10 (53\%) and the $4^{\prime}-C \beta$ OMe epimer 11 (17\%). The stereo configuration of both 10 and 11 were confirmed by COSY and NOESY NMR analysis. Subsequent dimethoxytritylation followed by desilylation gave DMTr-protected nucleosides 7 and 14. Phosphitylation of compounds 7 and $\mathbf{1 4}$ afforded the corresponding phosphoramidites $\mathbf{8}$ and $\mathbf{1 5}$ for incorporating into oligonucleotides, respectively. Succination of $\mathbf{7}$ and 14, followed by loading onto a controlled pore glass support, afforded solid supports 16 and 17, respectively. For the conformational analysis of the free nucleosides, compounds $\mathbf{7}$ and $\mathbf{1 4}$ were treated with $80 \%$ acetic acid to afford compound $\mathbf{6}$ and 18, respectively. 


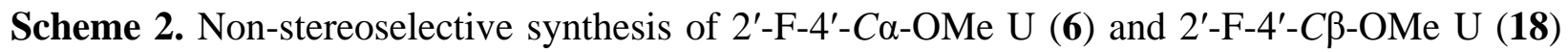
building blocks. ${ }^{\mathrm{a}}$
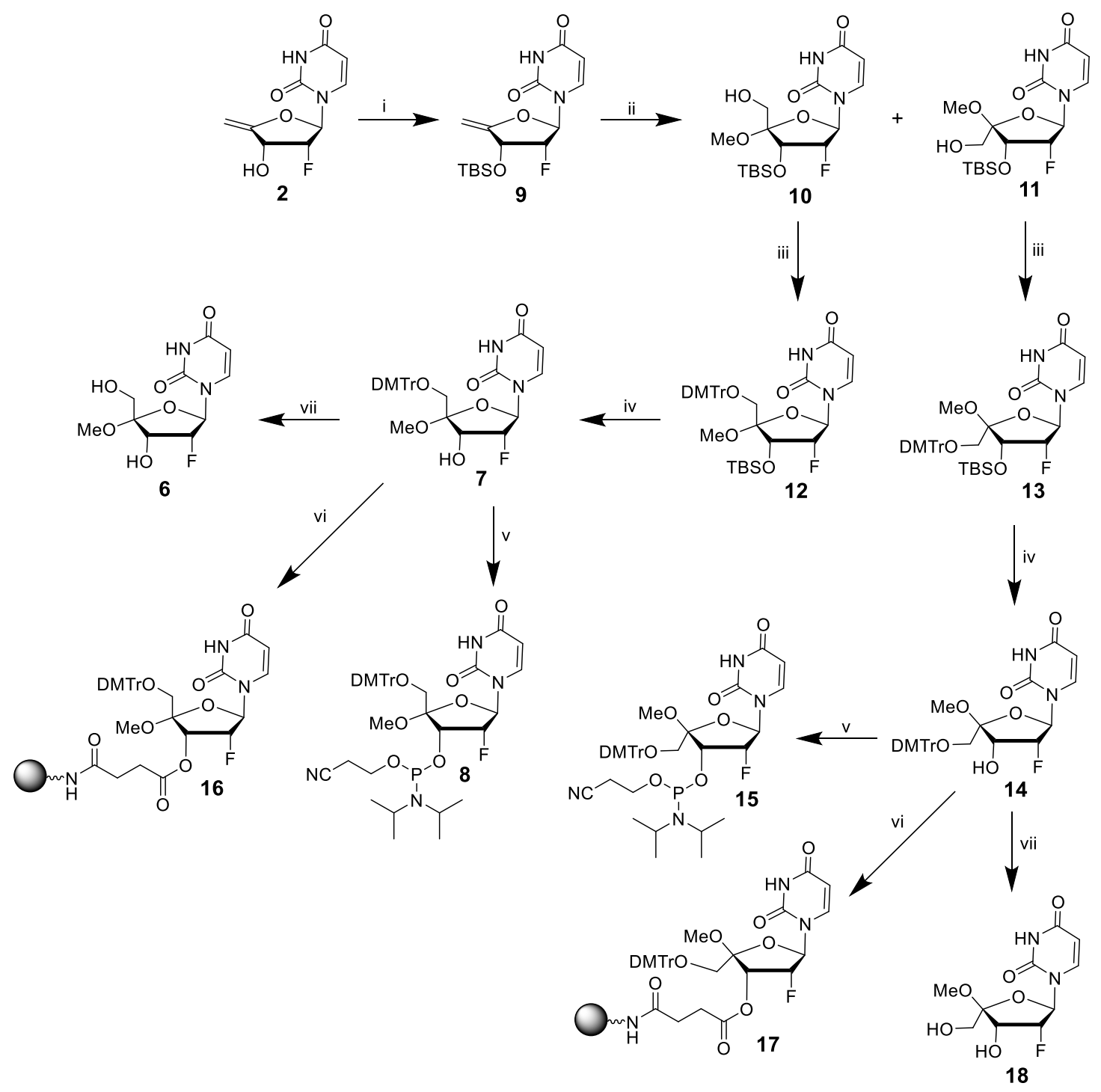

aReagents and conditions: (i) TBS-Cl, imidazole/pyridine, rt, overnight, 87\%; mCPBA/MeOH, rt, overnight, 10: 53\%, 11: 17\%; (iii) DMTr-Cl/pyridine, $0{ }^{\circ} \mathrm{C}, 14 \mathrm{~h}, 12: 89 \%$, 13: $89 \%$; (iv) $n$-TBAF/THF, rt, 2 h or overnight, 7: 68\%, 14: 61\%; (v) 2-cyanoethyl $N, N-$ diisopropylchlorophosphoramidite, DIEA/ $\mathrm{CH}_{2} \mathrm{Cl}_{2}$, rt, 16 h, 8: 86\%, 15: 41\%; (vi) (a) succinic anhydride, DMAP/CH $\mathrm{Cl}_{2}, 24 \mathrm{~h}$ (b) HBTU, DIEA/DMF/500 $⿱$ A controlled pore glass support (CPG), rt, 24 h, loading: $71 \mu \mathrm{mol} / \mathrm{g}$ for 16, $76 \mu \mathrm{mol} / \mathrm{g}$ for 17; (vii) 80\% AcOH, overnight, 6: 84\%, 18: $70 \%$. 


\section{Conformational analysis.}

We next explored the effect of the 4'-OMe substituent on the conformation of both epimers. In solution, the furanose ring of nucleosides exists in a conformational equilibrium between the North- and South-type sugar puckers. Based on the Karplus equation, it is possible to estimate the population of each conformer by analysis of the ${ }^{3} J_{\mathrm{H}-\mathrm{H}}$ values (coupling constant in $\mathrm{Hz}$ ) of the sugar ring abstracted from a ${ }^{1} \mathrm{H}-\mathrm{NMR}$ spectrum (Table 1). ${ }^{37,38}$ In the North-type conformation, the $\mathrm{H}^{\prime}$ and $\mathrm{H} 2^{\prime}$ adopt pseudoequatorial orientations (small $J$-value), whereas in the South conformation these protons exist in a trans pseudoaxial orientations (large $J$-value). The North

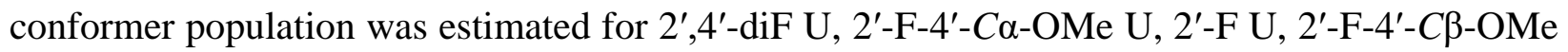
$\mathrm{U}$, and $\mathrm{rU}$ in various solvents (Table 1) by applying the following equation: North $(\%)=100-10$ $\times\left(J_{\mathrm{H} 1^{\prime} \mathrm{H} 2^{\prime}}\right){ }^{16}$

Table 1. Percent population of North conformer of nucleosides. ${ }^{a}$

\begin{tabular}{cccccc}
\hline Solvent & $2^{\prime}, 4^{\prime}-\mathrm{diF} \mathrm{U}$ & $\begin{array}{c}4^{\prime}-\mathrm{C} \alpha \text {-OMe- } \\
\text { 2'-F U (6) }\end{array}$ & 2'-F U & $\begin{array}{c}4^{\prime}-C \beta-\mathrm{OMe}- \\
2^{\prime}-\mathrm{F} \mathrm{U}(\mathbf{1 8})\end{array}$ & $\mathrm{rU}$ \\
\hline $\mathrm{D}_{2} \mathrm{O}$ & 100 & 87.0 & 85.0 & 44.0 & 55.5 \\
$\mathrm{CD}_{3} \mathrm{OD}$ & 100 & 86.0 & 81.0 & 41.0 & 54.0 \\
$d_{3}-\mathrm{MeCN}$ & 100 & 87.0 & 80.0 & 37.0 & 54.0 \\
$d_{6}$-DMSO & $\mathrm{nd}$ & 86.0 & 79.0 & 44.0 & 45.5 \\
\hline
\end{tabular}

${ }^{a}$ North $(\%)=100-10 \times\left(\mathrm{J}_{\mathrm{H} 1^{\prime}-\mathrm{H} 2^{\prime}}\right) . \mathrm{nd}=$ not determined. $2^{\prime}, 4^{\prime}$-diF $\mathrm{U}$ data obtained from ref 16.

The following trend was observed, irrespective of the solvent used: North (\%): 2'-F-4'-C $\beta-\mathrm{OMe}$ $\mathrm{U}<\mathrm{rU}<2^{\prime}-\mathrm{F} \mathrm{U}<2^{\prime}-\mathrm{F}-4^{\prime}-\mathrm{C} \alpha-\mathrm{OMe} \mathrm{U}<2^{\prime}, 4^{\prime}-\mathrm{diF} \mathrm{U}$. The electronegativity of the 2'-substituent plays a prominent role in shifting the sugar pucker equilibrium towards a North-type pucker (e.g., 2'-F U vs rU) due to the $\mathrm{O}^{\prime}-\mathrm{C} 1^{\prime}-\mathrm{C} 2^{\prime}-\mathrm{X} 2^{\prime}$ gauche effect. The presence of a pseudoaxial $\alpha-$ OMe substituent at $\mathrm{C}^{\prime}$ ' shifts the equilibrium even further to the North conformer, likely due to an anomeric hyperconjugation effect via the $\mathrm{O} 4^{\prime}-\left(n-\sigma^{*}\right)-\mathrm{X} 4^{\prime}$ overlap in this conformation (Figure $2 \mathrm{~A}$ - in blue). Conversely, the $\beta$-OMe substituent, can only participate in hyperconjugation when in the South-type conformer, resulting in competing stereoelectronic effects; the $2^{\prime}$-gauche effect 
stabilizes the North-type pucker, and the anomeric effect stabilizes the South-type pucker (Figure $2 \mathrm{~B}$ ), resulting in a 2:5 N/S equilibrium between the conformers.

To further explore the effect of the substituents at the $2^{\prime}$ - and $4^{\prime}$-positions, and the origin of the conformational preferences, we turned to computational methods. Molecular dynamics (MD) simulations allow for investigation of the hyperconjugation and solvent effects. ${ }^{39,40}$ The computational analysis $^{51}$ yielded two distinct energy minima for the $\mathrm{C} \alpha$-epimer (6), one at a pseudorotation phase angle $\mathrm{P}_{\mathrm{N}}=58.5^{\circ}$ (puckering amplitude $\phi_{\mathrm{m}}=42.9$ ), corresponding to the global minimum in the North-East conformation and one at $168.5^{\circ}$ (puckering amplitude $\phi_{\mathrm{m}}=$ 31.2), corresponding to a local minimum in the South conformation (Figure 2C). Molecular orbital analysis of the structures suggests that the anomeric effect (nO4' $\rightarrow \sigma^{*} \mathrm{C}^{\prime} \mathrm{O}$ ) in the case of the North pucker is more pronounced than in the South pucker, likely due to better no4' $\rightarrow \sigma^{*} \mathrm{C}^{\prime} \mathrm{O}$ overlap achieved when the orbitals are in an antiperiplanar orientation, as in the North-type sugar conformation $^{.51}$ These findings correlate with the experimentally determined population of the sugar conformation for the C $\alpha$-epimer ( 90\%; Table 1).

A
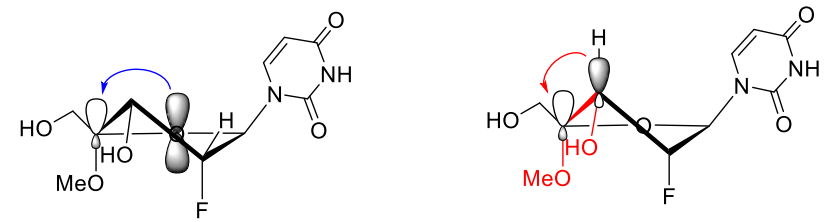

B

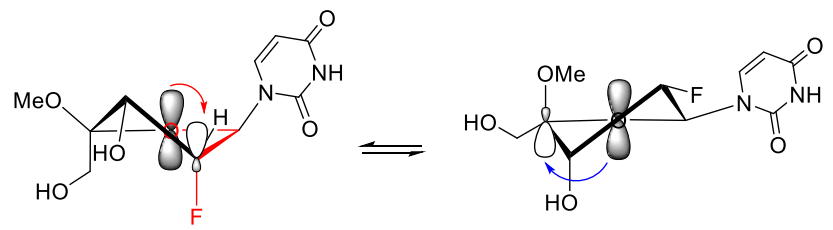

C

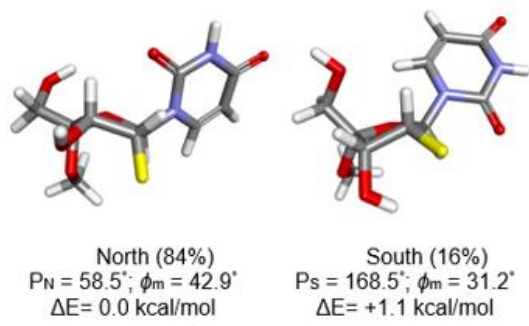

Figure 2. Some relevant, (A) Proposed anomeric (left) and gauche (right) interactions between $\mathrm{C} 2$ ' and $\mathrm{C}^{\prime}$ '-electronegative substituents that favor a North type sugar conformation in 2'-F-4'$C \square$-OMe U, ${ }^{51}$ and (B) Conformational equilibrium between the North and South puckers in 2'- 
F-4'-C $\beta$-OMe U showing the stereoelectronic effects stabilizing each conformation. Anomeric effects are represented in blue and gauche effects in red. (C) Computational analysis yielding the structures corresponding to the North and South minima of 2'-F-4'-Ca-OMe U.

In addition to the anomeric effects of $2^{\prime}-\mathrm{F}-4^{\prime}-C \square-\mathrm{OMe} \mathrm{U}(\mathbf{6})$, several gauche effects were revealed, which are known to significantly contribute to the conformational preference in fluorine containing nucleotides due to the polarity of fluorine. ${ }^{6,41}$ Most importantly, we observed that the $\sigma_{\mathrm{C} 3^{\prime}-\mathrm{H}} \rightarrow \sigma^{*} \mathrm{C}^{\prime}-\mathrm{O}$ gauche effect was prevalent in the North pucker of modified 2'-F U, while the South pucker exhibited this effect to a lesser extent, mainly due to the poor orbital overlap afforded by the South pucker. ${ }^{51}$ Additionally, intramolecular hydrogen bonding, due to electrostatic and polarization effects, was revealed by molecular orbital analysis in both the North and South sugar puckers of 6: three hydrogen bonds (H-bonds) were observed for the North conformation and only one observed for the South conformation (Figure S1). Since the $N / S$ pucker equilibrium affects the binding affinity of the oligonucleotide components forming duplexes, these monomers were incorporated into oligonucleotides in order to study their impact on duplex formation, and ultimately, their effect on siRNA activity.

\section{UV thermal melting.}

Oligonucleotides containing the 2'-F-4'-OMe U epimers were synthesized by following standard solid-phase synthesis protocols. ${ }^{42}$ The thermal denaturation temperatures $\left(T_{\mathrm{m}}\right)$ were measured for duplexes containing a single, centrally located modified nucleotide within homo- (DNA or RNA) and hetero- (DNA:RNA or RNA:DNA) duplexes, in two different sequence contexts (Table 2). 2'-F U was slightly destabilizing in DNA:DNA (30-31: $\Delta T_{\mathrm{m}}=-1.6$ to $\left.-0.5^{\circ} \mathrm{C}\right)$, but stabilizing in heteroduplexes or RNA:RNA duplexes (33-36: $\Delta T_{\mathrm{m}}=+0.7$ to $\left.+2.1{ }^{\circ} \mathrm{C}\right)$. It has been suggested that the increased thermal stability in A-type duplexes is due to improved strength of WatsonCrick base pairing caused by increased polarization of the nucleobase, ${ }^{9}$ as opposed to solely entropic contributions, such as the preorganization to the RNA-like C3'-endo sugar conformation.

In general, incorporation of $2^{\prime}-\mathrm{F}-4^{\prime}-\mathrm{C} \alpha$-OMe $\mathrm{U}$ resulted in similar trends in thermal stability as 2'-F U, albeit slightly more destabilizing. DNA:DNA duplexes 30-31 modified with the $4^{\prime}-C \alpha-$ OMe epimer were destabilized compared to the corresponding parent duplex $\left(\Delta T_{\mathrm{m}}=-4.2^{\circ} \mathrm{C}\right.$ and 
$\left.-1.0{ }^{\circ} \mathrm{C}\right)$. In hetero duplexes, 32-34, the effect of the $\mathrm{C} \alpha$-epimer was found to be sequence dependent but within $1.5^{\circ} \mathrm{C}$ of the unmodified duplex, while the thermal stability of modified RNA homoduplexes $\mathbf{3 5}$ and $\mathbf{3 6}$ were equivalent to the parent duplex $\left(\Delta T_{\mathrm{m}}=0{ }^{\circ} \mathrm{C}\right)$. This is similar to the corresponding duplexes containing $2^{\prime}, 4^{\prime}$-diF $\mathrm{U}$, where preorganization of the sugar pucker did not result in an increased $T_{\mathrm{m}}$. This was explained by the altered charge distribution on the furanose ring due to the inductive effect of the $\mathrm{C}^{\prime}-\mathrm{F}$, since it diminishes the polarization of the $2^{\prime} \mathrm{C}-\mathrm{H}^{\prime}$ bonds, and consequently, the potential to form $2^{\prime} \mathrm{C}-\mathrm{H} \cdots \mathrm{O} 4^{\prime} \mathrm{H}$-bond (a feature proposed to stabilize $2^{\prime}$-F RNA containing duplexes). ${ }^{43}$ This inductive effect would be less significant for the $\mathrm{C}^{\prime}$ '-OMe substituent, yet still be present, and would account for the reduced stabilizing effect compared to 2'-F U. Furthermore, the 4'-OMe group could plausibly cause a better hydration of the minor groove compared to the 4'-fluorine.

Oligonucleotides containing the $\mathrm{C} \beta$-epimer resulted in significant thermal destabilization of up to $8.9^{\circ} \mathrm{C}$ in both DNA and RNA homoduplexes 30 and $\mathbf{3 5}$ respectively which, as described below, is very likely due to backbone distortion and disrupted base-base stacking introduced by this modification. Interestingly, modification of the DNA:RNA heteroduplex is less detrimental to thermal stability $\left(\Delta T_{\mathrm{m}}=-4.7^{\circ} \mathrm{C}\right)$. Despite the destabilization, analysis by $\mathrm{CD}$ spectroscopy revealed no perturbation of the global duplex geometry (Figure S3), suggesting these modifications can be used to modulate thermal stability while maintaining the integrity of the Atype duplex.

Table 2. Comparison of the relative melting temperatures of duplexes containing a single incorporation of 2'- or 2',4'-modified uridine ${ }^{a}$

\begin{tabular}{|c|c|c|c|c|c|c|c|}
\hline \multirow[b]{2}{*}{ Duplex } & \multirow[b]{2}{*}{ ss } & \multirow[b]{2}{*}{ Sequence } & \multirow{2}{*}{$\frac{T_{\mathrm{m}}\left({ }^{\circ} \mathrm{C}\right)}{\mathbf{T} / \mathbf{U}}$} & \multicolumn{4}{|c|}{$\Delta T_{\mathrm{m}}\left({ }^{\circ} \mathrm{C}\right)$} \\
\hline & & & & $2^{\prime}-\mathrm{F}$ & $\alpha 4^{\prime}-\mathrm{OMe}$ & $\beta 4^{\prime}-\mathrm{OMe}$ & $2^{\prime}, 4^{\prime}-\operatorname{diF}^{c}$ \\
\hline \multirow{2}{*}{$\mathbf{3 0}^{b}$} & 19 & 5'-d(TACAG $\underline{\mathbf{X}} \mathrm{CTATGT)}$ & \multirow{2}{*}{42.9} & \multirow{2}{*}{-1.6} & \multirow{2}{*}{-4.2} & \multirow{2}{*}{-8.7} & \multirow{2}{*}{ nd } \\
\hline & 20 & 3'-d(ATGTCAGATACA) & & & & & \\
\hline \multirow[b]{2}{*}{$31^{a}$} & 21 & 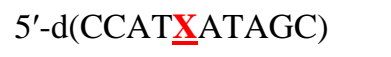 & \multirow[b]{2}{*}{31.5} & \multirow[b]{2}{*}{-0.5} & \multirow[b]{2}{*}{-1.0} & \multirow[b]{2}{*}{ nd } & \multirow[b]{2}{*}{ nd } \\
\hline & & & & & & & \\
\hline
\end{tabular}




\begin{tabular}{|c|c|c|c|c|c|c|c|}
\hline $32^{b}$ & $\begin{array}{l}19 \\
24\end{array}$ & $\begin{array}{l}\text { 5'-d(TACAGX्XTATGT) } \\
\text { 3'-r(AUGUCAGAUACA) }\end{array}$ & 41.5 & +2.1 & -1.2 & -4.7 & nd \\
\hline $\mathbf{3 3}^{a}$ & $\begin{array}{l}21 \\
26\end{array}$ & $\begin{array}{l}\text { 5'-d(CCAT吕ATAGC) } \\
\text { 3'-r(GGUAAUAUCG) }\end{array}$ & 29.5 & +2.0 & +1.5 & nd & -9.4 \\
\hline $34^{a}$ & $\begin{array}{l}27 \\
22\end{array}$ & $\begin{array}{l}\text { 5'-r(CCAU } \underline{X} A U A G C) \\
\text { 3'-d(GGTAATATCG) }\end{array}$ & 28.5 & +1.5 & +1.5 & nd & -1.5 \\
\hline $\mathbf{3 5}^{b}$ & $\begin{array}{l}28 \\
24\end{array}$ & $\begin{array}{l}\text { 5'-r(UACAGXXCUAUGU) } \\
\text { 3'-r(AUGUCAGAUACA) }\end{array}$ & 53.2 & +0.7 & 0 & -8.9 & nd \\
\hline $36^{a}$ & $\begin{array}{l}27 \\
26\end{array}$ & $\begin{array}{l}\text { 5'-r(CCAU } \underline{X} A U A G C) \\
\text { 3'-r(GGUAAUAUCG) }\end{array}$ & 39.5 & +1.5 & 0 & nd & -0.5 \\
\hline
\end{tabular}

${ }^{a} T_{\mathrm{m}}$ values were measured in $10 \mathrm{mM}$ sodium phosphate buffer (pH 7.2) containing $100 \mathrm{mM}$ $\mathrm{NaCl}$ and $0.1 \mathrm{mM}$ EDTA with a strand concentration of $1.5 \mu \mathrm{M} . \Delta T_{\mathrm{m}}=\left(T_{\mathrm{m}}\right.$ of modified duplex $T_{\mathrm{m}}$ of corresponding unmodified duplex). $\underline{\mathbf{X}}$ indicates the modified nucleotide: $\alpha 4^{\prime}-\mathrm{OMe}=2^{\prime}-\mathrm{F}-$ $4^{\prime}-C \alpha-O M e \mathrm{U}, \beta 4^{\prime}-\mathrm{OMe}=2^{\prime}-\mathrm{F}-4^{\prime}-C \beta-\mathrm{OMe} \mathrm{U}$. $T_{\mathrm{m}}$ values were determined as the maximum of the first-derivative of the melting curve $\left(A_{260}\right.$ vs $\left.T\right)$ and reported as the average of two independent experiments. ${ }^{b} T_{\mathrm{m}}$ values were measured in phosphate-buffered saline $\left(\left[\mathrm{Na}^{+}\right]=147\right.$ $\left.\mathrm{mM},\left[\mathrm{K}^{+}\right]=4.5 \mathrm{mM},\left[\mathrm{Cl}^{-}\right]=140 \mathrm{mM}, \mathrm{pH} 7.4, \mathrm{NaH}_{2} \mathrm{PO}_{4} / \mathrm{Na}_{2} \mathrm{HPO}_{4}\right)$ with a strand concentration of $2.5 \mu \mathrm{M} .{ }^{c} 2^{\prime}, 4^{\prime}-$ diF data obtained from ref $16 . \mathrm{nd}=$ not determined.

\section{Nuclease Resistance.}

The 2'-F modification has been recognized as a most valuable nucleotide modification for enhancing potency of chemically modified siRNAs, however, it does not impart significant metabolic stability to the duplexes. ${ }^{11}$ In order to assess the stability of both $2^{\prime}-\mathrm{F}-4^{\prime}-C$-OMe U epimers towards nucleases, we incorporated these modifications into either the 3 '- or 5 '-terminus of a poly-dT oligonucleotide and incubated with either a 3'- or 5'-specific exonuclease, respectively (Figure 3). The degradation of full length oligonucleotide in the presence of the nuclease was monitored using ion-exchange HPLC by consecutive injections every hour for $24 \mathrm{~h}$ under these conditions. When a single or a double incorporation of 2 '-F $U$ in the context of a 
phosphodiester backbone, $\mathbf{3 7}\left(\mathbf{2}^{\prime}-\mathbf{F}\right)$ and 38(2'-F), was incubated with $3^{\prime}$-specific endonuclease, snake venom phosphodiesterase (SVPD), it was rapidly degraded within $<1 \mathrm{~h}$ (Figure 3A), and incorporation of $2^{\prime}-\mathrm{F}-4{ }^{\prime}-\mathrm{C} \alpha-\mathrm{OMe} \mathrm{U} \mathbf{3 7}(\alpha)$ and $\mathbf{3 8}(\alpha)$ somewhat increased the enzymatic stability to $\sim 1$ h. However, incorporation of the corresponding $C \beta$ epimer $37(\boldsymbol{\beta})$ and $\mathbf{3 8}(\boldsymbol{\beta})$ provided oligomers that were completely stable towards SVPD with no degradation observed within $24 \mathrm{~h}$. When a terminal phosphorothioate (PS) linkage was present (Figure 3D), increased protection against SVPD degradation was observed for all modified oligonucleotides. It is interesting to note that sequential modifications with 2'-F U or 2'-F-4'-Ca-OMe U with a PS linkage between them $40\left(2^{\prime}-\mathbf{F}\right)$ or $40(\alpha)$ appeared to be less stable than the corresponding singly incorporated oligonucleotides $39\left(2^{\prime}-\mathbf{F}\right)$ or $39(\alpha)$, respectively.

$\mathbf{A}$

$37(\underline{\mathbf{X}}): 5^{\prime}-\mathrm{dT}_{19} \underline{\mathrm{X}}$

$38(\underline{\underline{X}}): 5^{\prime}-\mathrm{dT}_{18} \underline{\underline{\mathbf{X}}}_{2}$

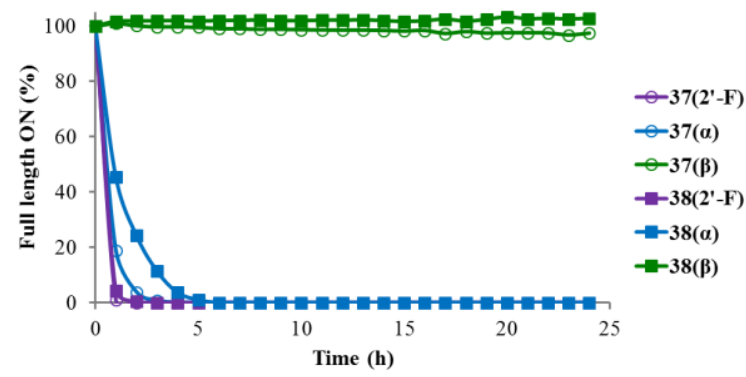

C

$41(\underline{X}): 5^{\prime}-\underline{X} \mathrm{dT}_{19}$ 42( $\underline{\mathbf{X}}): 5^{\prime}-\underline{\underline{X}} \cdot 19 T_{19}$

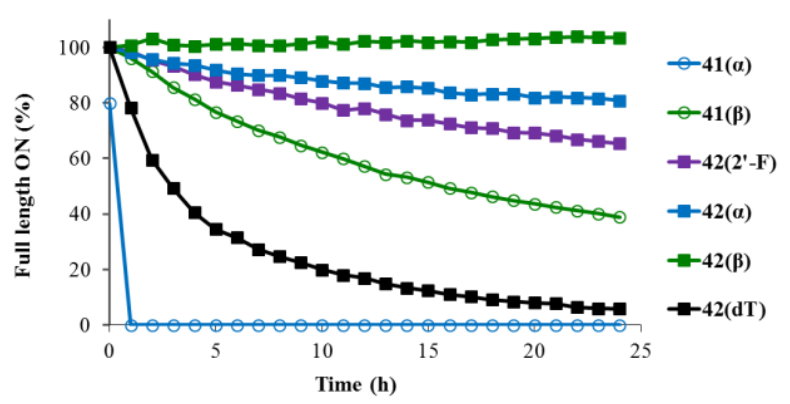

B

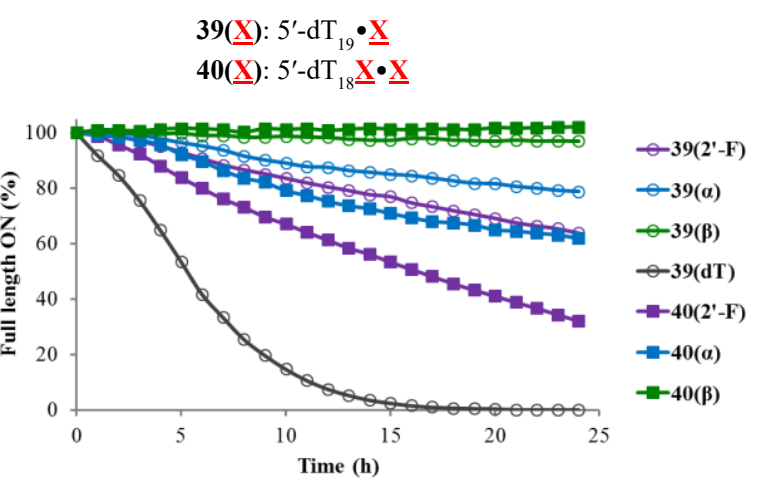

D

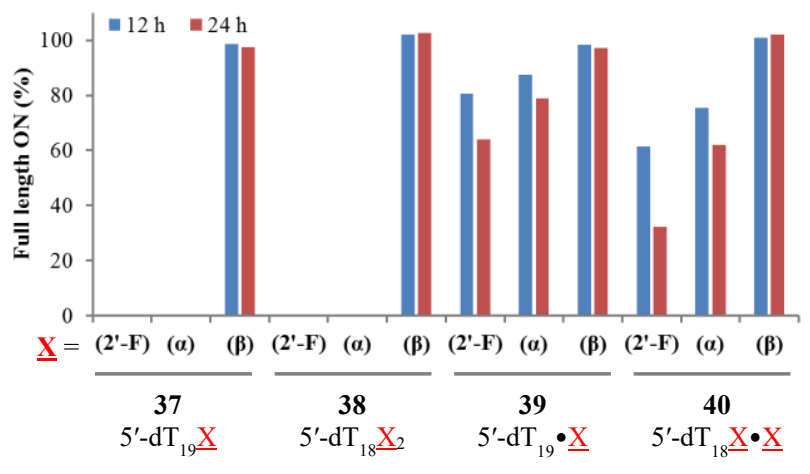

Figure 3. Decay curves of 3'- or 5'-terminally modified oligonucleotides $(0.1 \mathrm{mg} / \mathrm{mL})$ in the presence of 3 '-specific exonuclease (SVPD; $150 \mathrm{mU} / \mathrm{mL}$ ) in $50 \mathrm{mM}$ Tris $(\mathrm{pH} 7.2)$ buffer supplemented with $10 \mathrm{mM} \mathrm{MgCl}_{2}$ (A and B) or 5'-specific exonuclease (phosphodiesterase II; $500 \mathrm{mU} / \mathrm{mL}$ ) in $50 \mathrm{mM}$ sodium acetate buffer ( $\mathrm{pH} 6.5)$ with $10 \mathrm{mM} \mathrm{MgCl} 2(\mathrm{C})$ and monitored 
using IEX-HPLC at A260. The percentages of full length oligonucleotide at specified time points are shown in (D). $\underline{\mathbf{X}}$ represents modified nucleotides: 2'-F U (2'-F), 2'-F-4'-C $\alpha-\mathrm{OMe} U(\alpha), 2^{\prime}-\mathrm{F}-$ $4^{\prime}-C \square$-OMe U $(\beta)$, PS linkage $(\bullet)$. Percentage full length oligonucleotide is calculated by dividing the area under the peak corresponding to full length oligonucleotide at a given time point by the full length at $t=0$ and multiplied by 100 .

Incubation of 5'-modified oligonucleotides with phosphodiesterase II, a 5'-specific exonuclease, largely recapitulated the findings with SVPD, where the $4^{\prime}-C \alpha-O M e$ epimer provided greater protection against exonuclease degradation compared to the corresponding unmodified thymidine oligonucleotides $39(\mathbf{d T})$ or $\mathbf{4 2}(\mathbf{d T})$, particularly in combination with a terminal PS linkage. The 4'-C $C$-OMe epimer, however, provided excellent stability towards exonucleases, even with a single incorporation in combination with a full PO backbone $(\mathbf{3 7}(\boldsymbol{\beta})$ and $\mathbf{4 1}(\boldsymbol{\beta}))$. The structural features of $2^{\prime}-\mathrm{F}-4$ '-OMe $\mathrm{U}$ facilitating this protection against nucleases was examined by X-ray crystallography and subsequent modeling.

\section{Crystal structure of an RNA duplex modified with $2^{\prime}-\mathrm{F}-4^{\prime}-\mathrm{C} \alpha-\mathrm{OMe} \mathrm{U}$.}

To visualize the conformation of 2'-F-4'-C $\alpha$-OMe U incorporated into a double-stranded RNA, we determined at $1.5 \AA$ resolution the X-ray crystal structure of the palindromic RNA duplex [5'-

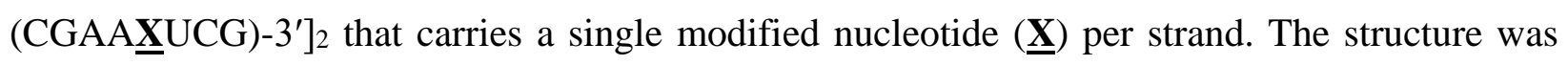
phased using the molecular replacement technique (see Experimental Section for details), and selected crystal data, data collection and refinement parameters are listed in Table S2, and an example of the quality of the final Fourier $2 \mathrm{~F}_{o}-\mathrm{F}_{c}$ sum electron density is depicted in Figure 4A. The asymmetric unit of the tetragonal crystals contains two independent duplexes that allow observation of the conformational properties of four $2^{\prime}-\mathrm{F}-4^{\prime}-\mathrm{C} \alpha-\mathrm{OMe} \mathrm{U}$ units. All four nucleotides adopt virtually identical conformations, as do the two independent duplexes (r.m.s.d. of $0.3 \AA$ for 338 atom pairs). The duplex conformation of the modified RNA is nearly identical with that of a reference duplex with dT (PDB ID 5DEK, r.m.s.d. $0.3 \AA$ ). ${ }^{44}$ The structure of $2^{\prime}$-F4'-C $\alpha$-OMe U with the 5'- and 3'-adjacent $A$ and U nucleotides, respectively, from one RNA strand is depicted in Figure 4B. The sugar pucker of $2^{\prime}-\mathrm{F}-4^{\prime}-\mathrm{C} \alpha-\mathrm{OMe} \mathrm{U}$ is $\mathrm{C} 3^{\prime}$-endo, consistent with the anticipated gauche and anomeric effects (Figure 2). The methoxy group is directed toward the ribose 2 -hydroxyl $\left(2^{\prime}-\mathrm{OH}\right)$ group of the preceding residue, but the methyl group and $2^{\prime}-\mathrm{OH}$ are separated by $c a .4 \AA$ and the spacing thus exceeds the sum of their van der Waals 
radii. The almost ideal antiperiplanar orientation of the methoxy and $\mathrm{C} 4{ }^{\prime}-\mathrm{C} 3^{\prime}$ bonds positions the methyl group of the substituent at roughly equal distances from the 5 '- and 3 '-phosphate groups (Figure 4B). The relatively close association of the methyl group with backbone phosphates is probably the main reason for the increased protection against exonuclease degradation afforded by the 2'-F-4'-C $\alpha$-OMe modification. The distance of around $5.5 \AA$ between methyl carbon and neighboring phosphate groups somewhat exceeds the corresponding shortest separations for methyl moieties seen in RNAs with $5^{\prime}-C$-methyl-substituted nucleotides (Figure S5) ${ }^{44}$, but is comparable to those observed in structures of RNAs carrying cEt or cMOE BNA residues (Figure 4C and S5) ${ }^{45}$. A model of an RNA trimer based on the crystal structure of the 4'-OMemodified RNA, but with a $\beta$-configuration of the 4'-OMe substituent, reveals a tight spacing of ca. $4 \AA$ between methyl group and $5^{\prime}$ - and 3 '-adjacent phosphates (Figure 4D). The close vicinity of the hydrophobic moiety and neighboring phosphates might help rationalize the excellent protection against nucleases resulting from the $2^{\prime}-\mathrm{F}-4^{\prime}-C \beta-\mathrm{OMe}$ modification; however, it is important to keep in mind that the model of the $2^{\prime}-\mathrm{F}-4^{\prime}-C \beta$-OMe U-modified backbone suggests disrupted stacking (Figure 4D, orange star), which would explain, at least in part, the duplex destabilization effect introduced by this modification. Visualization of the conformational consequences of incorporation of a $2^{\prime}-\mathrm{F}-4{ }^{\prime}-C \beta-\mathrm{OMe} \mathrm{U}$ into an RNA has to await experimental structure determination of a modified RNA that is underway in our laboratories. 

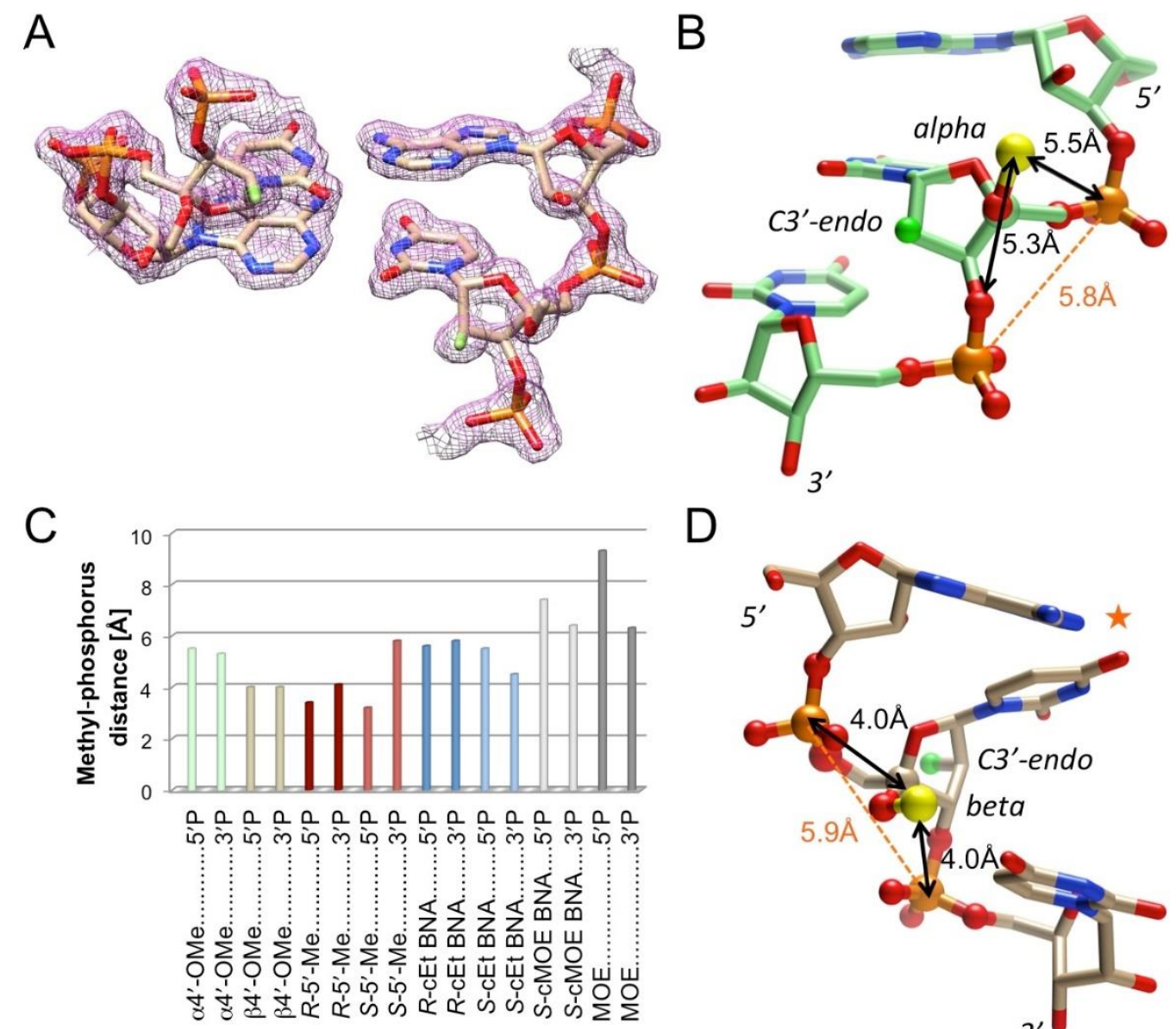

Ribose modification

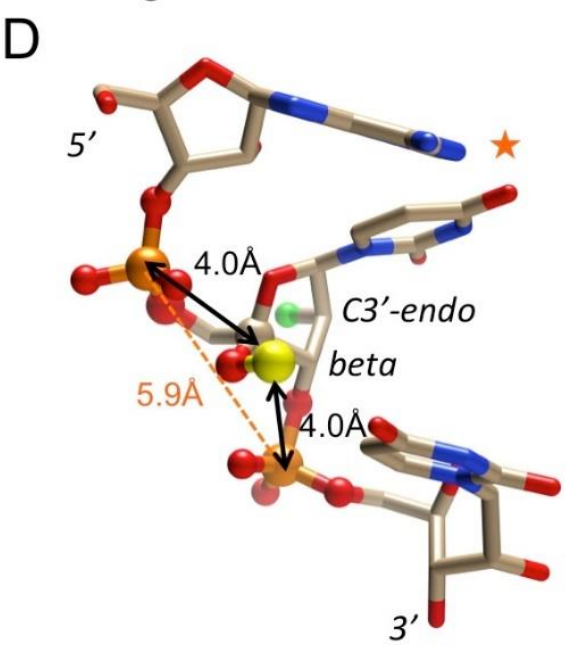

Figure 4. Conformational properties of 2'-F-4'-C-OMe U-modified RNA. (A) Quality of the Fourier $2 \mathrm{~F}_{o}-\mathrm{F}_{c}$ sum electron density ( $1 \sigma$ level) around a dimer step of the final model of an RNA duplex containing 2'-F-4'-Ca-OMe Us. (B) Conformation of the 5'-A[2'-F-4'-Ca-OMe U]U-3' trimer in the modified octamer duplex. 4'-OMe carbon and 2'-fluorine are highlighted with yellow and green spheres, respectively, and selected distances are indicated with thin solid and dashed lines. (C) Comparison between methyl...phosphate distances for selected ribose

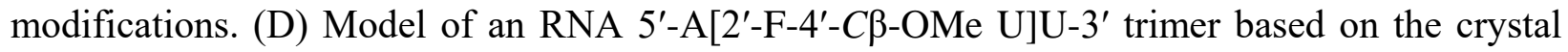
structure of the 4'-methoxy-modified RNA duplex with the substituent in the $\alpha$-configuration (panel B). Backbone torsion angles (except for $\delta$ around the $\mathrm{C}^{\prime}-\mathrm{C} 3{ }^{\prime}$ bond - to retain the $\mathrm{C} 3^{\prime}-$ endo pucker of the ribose) were adjusted to accommodate the $\beta$-configuration of the methoxy substituent at $\mathrm{C}^{\prime}$. The relative orientation of the flanking $\mathrm{A}$ and $\mathrm{U}$ nucleosides is identical to that in figure panel B. Note the clash between uracil of the modified nucleotide and the $5^{\prime}$-adjacent adenine base (orange star). 


\section{siRNA activity.}

The RNA-like nature of 2'-F-4'-Ca-OMe U, and its minimal impact on thermal affinity in RNA duplexes, prompted us to assess this modification's impact on siRNA to elicit in vitro RNAimediated gene silencing. As such, siRNAs were designed to target either transthyretin (Ttr) or firefly luciferase (Luc) mRNA. With this aim, we first evaluated both the $\mathrm{C} \alpha$ - and $\mathrm{C} \beta$-epimers in the context of an optimized siRNA targeting mouse Ttr mRNA: a 21-mer duplex with a two nucleotide 3'-overhang on the antisense strand, fully modified 2'-OMe and 2'-F substituted nucleotides, and six PS linkages used to stabilize the termini (Figure 5B). The 3 '-end of the sense strand included a trivalent GalNAc ligand, which facilitates ASGPR-mediated hepatocellular uptake. $^{46}$ Modified siRNA in increasing concentrations $(0.036 \mathrm{pM}$ to $10 \mathrm{nM})$ was transfected into primary mouse hepatocytes using RNAiMax. After $20 \mathrm{~h}$ incubation, the amount of Ttr mRNA remaining was quantitated using real-time qPCR. IC 50 -values and the corresponding dose-response graphs are reported in Figure 5 and S6, where the optimized siRNA parent, 50, showed excellent activity with an IC50-value of 0.08 nM. siRNA 53 containing three incorporations of the $\mathrm{C} \alpha$ epimer on the antisense strand at positions 4, 18 and 20, minimally reduced potency $\left(\mathrm{IC}_{50}=0.29 \mathrm{nM}\right)$. The $4^{\prime}-C \alpha$-OMe epimer was well tolerated on the sense strand at position 11 in siRNA 51, with similar activity to the parent (IC50 of $0.057 \mathrm{nM}$ vs $0.078 \mathrm{nM}$ ). However, siRNA 52 containing a single incorporation of the 4'-C $\alpha$-OMe epimer at position 2 of the antisense strand significantly reduced the potency $\left(\mathrm{IC}_{50}=1.3 \mathrm{nM}\right)$ and highlighted the positional dependence of this modification on RNAi activity and the importance of potential steric effects in spite of the preferred C3'-endo sugar pucker like the parent compound. Consistent with this explanation, the loss of activity is even more pronounced with the $4^{\prime}-C \beta$ epimer. The 4'-C $\beta$-OMe epimer reduced the potency of the siRNA when incorporated into the antisense strand at position 2 by 48 -fold $\left(55 \mathrm{IC}_{50}=3.8 \mathrm{nM}\right)$, but incorporation into the sense strand at position 11 was more tolerated with a 23 -fold loss in activity $\left(54 \mathrm{IC}_{50}=1.8 \mathrm{nM}\right)$. 


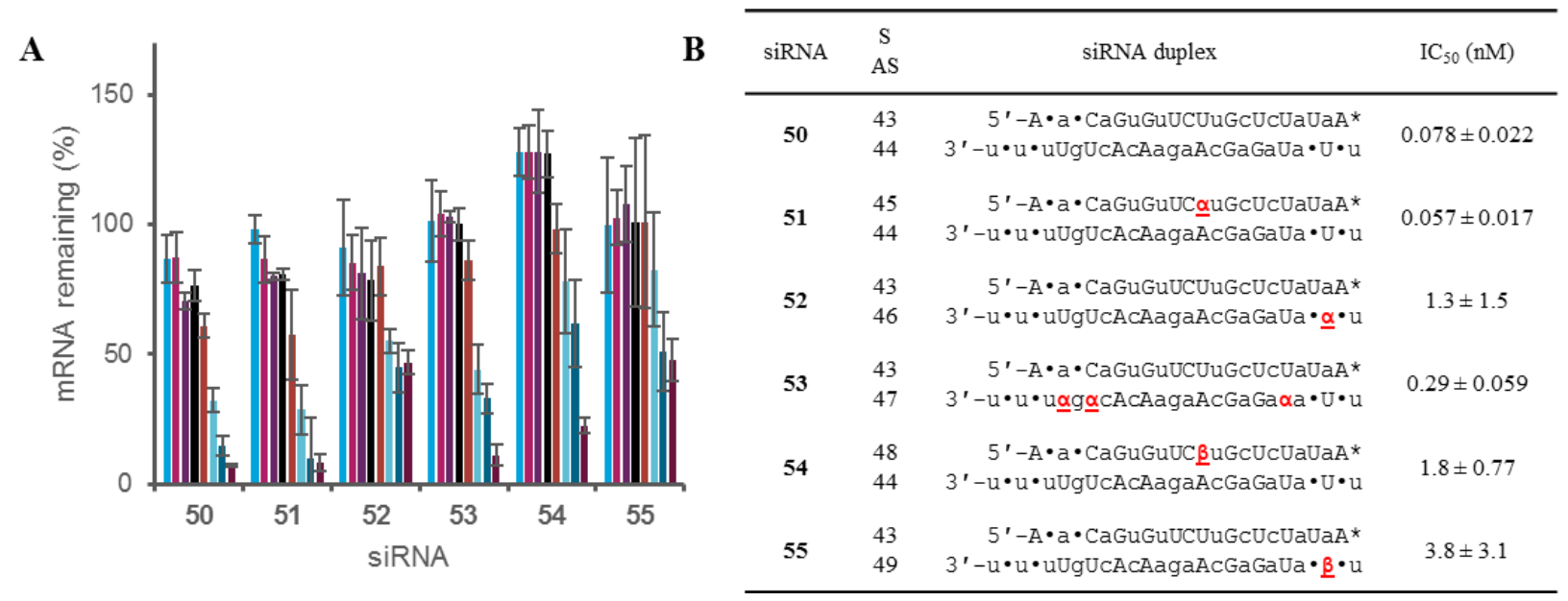

Figure 5. In vitro potency ( $\left.\mathrm{IC}_{50}\right)$ was evaluated for fully modified siRNA, which were transfected into primary mouse hepatocytes, and target mRNA quantified after $24 \mathrm{~h}$. (A) Doseresponse graphs ([siRNA] $=36 \mathrm{pM}$ to $10 \mathrm{nM})$ and the corresponding IC $_{50}$ values $(\mathrm{B})$ are reported as the mean values \pm SEM of four biological replicates. Modified nucleotides are as follows: $2^{\prime}-\mathrm{F}$

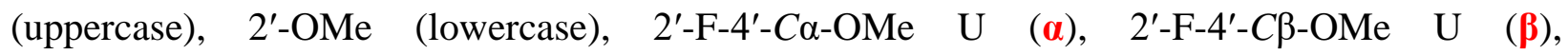
phosphorothioate $(\bullet)$, GalNAc ligand ${ }^{46}(*)$. For fitted IC50 curves, see Figure S6.

To further explore the effect of 2'-F-4'-C $\alpha$-OMe U on RNAi activity, several other siRNA motifs targeting Luc mRNA were prepared. Modifications were introduced at three positions of the antisense strand (including the seed region, nucleotides 2-8) or five positions of the sense strand, including the double nucleotide 3'-overhang (Figure S7A). For comparison, 2'-F U siRNA modified in the same positions were also included in the study along with an unmodified positive control and a scrambled negative control. The resulting modified siRNA duplexes were transfected into HeLa cells stably expressing firefly luciferase, and the reduction of Luc mRNA and subsequent knockdown of the downstream luciferase protein, was evaluated in a dose response manner (Figure S7C). In the antisense strand, the introduction of 2'-F-4'-Ca-OMe U was well tolerated, with gene silencing comparable to that of $2^{\prime}-\mathrm{F}$ U. It was also well tolerated in the sense strand where five incorporations of the $\mathrm{C} \alpha$ epimers resulted in siRNAs with gene knockdown efficiency similar to the native positive control siRNA. In summary, all modifications demonstrated robust luciferase knockdown (>70\% relative to negative control). Additionally, circular dichroism (CD) experiments were performed (Figure S4) for the 2'-F-4'$C \alpha$-OMe U modified siRNA. In all cases CD spectra show positive and negative bands at 260 
$\mathrm{nm}$ and $210 \mathrm{~nm}$, respectively, characteristic of the A-form structure adopted by RNA duplexes. This suggests that even multiple incorporations of 2'-F-4'-C $\alpha$-OMe $U$ has minimal impact on RNA duplex structure, thus lending to the compatibility with RNAi machinery. ${ }^{47}$

\section{Conclusions.}

In summary, we have developed simple and high yielding procedures for the stereoselective synthesis of a 4'-Ca-OMe-2'-F U nucleoside analogue. Furthermore, we demonstrated the synthetic feasibility of the $3^{\prime}$-phosphoramidites of both $2^{\prime}-\mathrm{F}-4^{\prime}-C \alpha-\mathrm{OMe} \mathrm{U}$ and $2^{\prime}-\mathrm{F}-4{ }^{\prime}-C \beta-\mathrm{OMe}$ $\mathrm{U}$ epimers, as well as subsequent incorporation into oligonucleotides using standard solid phase synthesis protocols. Modification of 2'-F U with 4'-C-methoxy substituents can be used to modulate the ribose sugar conformation towards $\mathrm{C} 3^{\prime}$-endo/East $\left(4^{\prime}\right.$-C $\mathrm{C}$-isomer) or closer to a

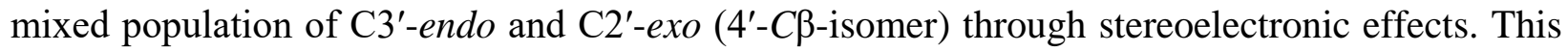
observation was supported by computational calculations, which suggests that additional anomeric and gauche effects shift the conformational equilibrium of the $\alpha$-epimer to a North-type sugar pucker. The incorporation of $2^{\prime}-\mathrm{F}-4^{\prime}-C-\mathrm{OMe} U$ in the DNA strand of a DNA:RNA duplex resulted in a small increase or small decrease in thermal stability, while the corresponding 4'-C $\beta$ isomer was significantly destabilizing in the same context. Even with the observed thermal destabilization, these modifications do not perturb the global geometry of the duplex as demonstrated by CD spectroscopy. When 2'-F-4'-C $\alpha$-OMe U was inserted into an RNA strand, the thermal stability with complementary DNA or RNA increased or remained neutral compared to the unmodified parent - a desirable feature for gene silencing applications.

Notably, the 4'-OMe substituent led to increased nuclease resistance, as demonstrated with both 5 '- and 3 '-specific exonucleases. X-ray crystallography data of a duplex containing the $\alpha$-epimer, where the relatively close association of the methyl group with the backbone phosphates likely contributes to the enhanced protection. The $\beta$-epimer was modeled in this context and revealed an even closer proximity of the phosphates to the methyl group, which is in accordance with the remarkable nuclease stability of this monomer. In general, the 2'-F-4'-Ca-OMe epimer showed position-dependent tolerance on both sense and antisense strands. Even with multiple incorporations at select positions, modified siRNA resulted in similar in vitro RNAi-mediated gene silencing as that of the parent siRNA. These data suggest that the in vivo RNAi activity of siRNAs with this modification may demonstrate enhanced duration of silencing activity. Overall, 
2'-deoxy-2'-fluoro-4'-C-methoxy-sugar-modified nucleotides add to the 'toolbox' of chemical modifications compatible with RISC machinery and can be used to advance RNAi therapeutics, as well as other nucleic acid based applications such as ribozymes and aptamers. Further evaluation of these modifications in combination with other nucleobases are in progress in our laboratories to understand the full potential of these modifications for modulating properties needed for efficient RNAi therapeutics.

\section{Experimental Section.}

Stereoselective Synthesis

4',5'-Didehydro-2',5'-dideoxy-2'-fluorouridine (2). A solution of $\mathbf{1}$ (3.21 g, $9.04 \mathrm{mmol})$ was prepared in anhydrous THF $(82 \mathrm{~mL})$ under inert atmosphere. 1,8-Diazabicyclo[5.4.0]undec-7ene (DBU) was added dropwise to the solution $(8.1 \mathrm{~mL}, 54 \mathrm{mmol})$ over a period of $5 \mathrm{~min}$. The reaction was left to stir at room temperature overnight. The reaction mixture was then evaporated and purified by column chromatography $\left(1-12 \% \mathrm{MeOH} / \mathrm{CH}_{2} \mathrm{Cl}_{2}\right)$ to afford the alkene 2 as a white foam (1.71 g, 83\%). $\mathrm{Rf}\left(10 \% \mathrm{MeOH} / \mathrm{CH}_{2} \mathrm{Cl}_{2}\right)$ : 0.38; ${ }^{1} \mathrm{H} \mathrm{NMR}\left(500 \mathrm{MHz}, \mathrm{CD}_{3} \mathrm{OD}\right) \delta 7.49$ $(\mathrm{d}, J=8.1 \mathrm{~Hz}, 1 \mathrm{H}), 6.03(\mathrm{dd}, J=17.4,1.6 \mathrm{~Hz}, 1 \mathrm{H}), 5.72(\mathrm{~d}, J=8.1 \mathrm{~Hz}, 1 \mathrm{H}), 5.18$ (ddd, $J=52.6$, $5.2,1.5 \mathrm{~Hz}, 1 \mathrm{H}), 4.93-4.85(\mathrm{~m}, 1 \mathrm{H}), 4.61(\mathrm{t}, J=2.1 \mathrm{~Hz}, 1 \mathrm{H}), 4.39(\mathrm{t}, J=2.1 \mathrm{~Hz}, 1 \mathrm{H}) .{ }^{13} \mathrm{C} \mathrm{NMR}$ $\left(126 \mathrm{MHz}, \mathrm{CD}_{3} \mathrm{OD}\right) \delta 166.2,162.6,151.9,142.7,103.5,93.5,92.0,86.0,69.8 .{ }^{19} \mathrm{~F}$ NMR $(471$ $\left.\mathrm{MHz}, \mathrm{CD}_{3} \mathrm{OD}\right) \delta$-202.53, -202.57, -202.61, -202.64, -202.68, -202.72. HRMS (ESI ${ }^{+}$) m/z calcd for $\mathrm{C}_{9} \mathrm{H}_{9} \mathrm{FN}_{2} \mathrm{NaO}_{4}[\mathrm{M}+\mathrm{Na}]^{+} 251.0439$, found 251.0440 .

2',5'-Dideoxy-2'-fluoro-5'-iodo-4'-Ca-methoxyuridine (3). A suspension of alkene 2 (1.71 g, $7.51 \mathrm{mmol})$ and $\mathrm{PbCO}_{3}(4.01 \mathrm{~g}, 15.0 \mathrm{mmol})$ was prepared in anhydrous methanol $(48 \mathrm{~mL}) . \mathrm{A}$ solution of iodine $(3.81 \mathrm{~g}, 15.0 \mathrm{mmol})$ in methanol $(30 \mathrm{~mL})$ was added dropwise to the rapidly stirring solution at $0{ }^{\circ} \mathrm{C}$. The reaction was left to stir overnight at room temperature, the solvents were concentrated under vacuum, and the resulting residue was purified by column chromatography (2-5\% $\mathrm{MeOH} / \mathrm{CH}_{2} \mathrm{Cl}_{2}$ ) to afford compound 3 as an orange foam (1.94 g, 67\%). $\mathrm{R}_{\mathrm{f}}\left(10 \% \mathrm{MeOH} / \mathrm{CH}_{2} \mathrm{Cl}_{2}\right): 0.71 ;{ }^{1} \mathrm{H}$ NMR $\left(500 \mathrm{MHz}, \mathrm{CD}_{3} \mathrm{OD}\right) \delta 7.65(\mathrm{~d}, J=8.1 \mathrm{~Hz}, 1 \mathrm{H}), 5.86$ $(\mathrm{dd}, J=21.2,1.7 \mathrm{~Hz}, 1 \mathrm{H}), 5.71(\mathrm{~d}, J=8.0 \mathrm{~Hz}, 1 \mathrm{H}), 5.16(\mathrm{ddd}, J=54.3,6.3,1.7 \mathrm{~Hz}, 1 \mathrm{H}), 4.63$ (dd, $J=20.3,6.2 \mathrm{~Hz}, 1 \mathrm{H}), 3.65(\mathrm{~d}, J=11.5 \mathrm{~Hz}, 1 \mathrm{H}), 3.53(\mathrm{~d}, J=11.5 \mathrm{~Hz}, 1 \mathrm{H}), 3.41(\mathrm{~s}, 3 \mathrm{H}) .{ }^{13} \mathrm{C}$ NMR (126 MHz, CD $3 \mathrm{OD}) \delta 166.0,151.7,144.4,105.1,103.2,93.9,92.6,92.3,74.5,1.91 .{ }^{19} \mathrm{~F}$ 
NMR (471 MHz, CD 3 OD) $\delta-196.27,-196.31,-196.36,-196.39,-196.43,-196.48 . \quad M S\left(\mathrm{ESI}^{+}\right)$ $\mathrm{m} / \mathrm{z}$ calcd for $\mathrm{C}_{10} \mathrm{H}_{12} \mathrm{FIN}_{2} \mathrm{NaO}_{5}[\mathrm{M}+\mathrm{Na}]^{+}$408.9667, found 408.9661 .

3'-O-Benzoyl-2',5'-dideoxy-2'-fluoro-5'-iodo-4'-Ca-methoxyuridine (4). A solution of nucleoside 3 (1.94 g, $5.03 \mathrm{mmol})$ was prepared in pyridine $(7 \mathrm{~mL})$. Benzoyl chloride $(700 \mu \mathrm{L}$, $6.03 \mathrm{mmol}$ ) was slowly added dropwise to the mixture, and the reaction was left to stir at room temperature overnight, following which the solvents were concentrated under vacuum. The resulting residue was purified by column chromatography (2-5\% $\mathrm{MeOH} / \mathrm{CH}_{2} \mathrm{Cl}_{2}$ ) to afford the desired product 4 as an orange solid (2.12 g, 86\%): $\mathrm{R}_{\mathrm{f}}\left(10 \% \mathrm{MeOH} / \mathrm{CH}_{2} \mathrm{Cl}_{2}\right)$ 0.74; ${ }^{1} \mathrm{H} \mathrm{NMR}(500$ $\left.\mathrm{MHz}, \mathrm{CD}_{3} \mathrm{OD}\right) \delta 8.55(\mathrm{dt}, J=4.5,1.7 \mathrm{~Hz}, 1 \mathrm{H}), 8.15-8.11(\mathrm{~m}, 2 \mathrm{H}), 7.92(\mathrm{~d}, J=8.1 \mathrm{~Hz}, 1 \mathrm{H})$, $7.80-7.74(\mathrm{~m}, 1 \mathrm{H}), 7.69-7.64(\mathrm{~m}, 1 \mathrm{H}), 6.03(\mathrm{dd}, J=21.6,1.7 \mathrm{~Hz}, 1 \mathrm{H}), 5.94(\mathrm{~d}, J=8.1 \mathrm{~Hz}$, $1 \mathrm{H}), 5.65(\mathrm{dd}, J=6.5,1.6 \mathrm{~Hz}, 1 \mathrm{H}), 5.62(\mathrm{~d}, J=6.4 \mathrm{~Hz}, 1 \mathrm{H}), 3.69(\mathrm{~d}, J=11.5 \mathrm{~Hz}, 1 \mathrm{H}), 3.56(\mathrm{~d}, J$ $=11.5 \mathrm{~Hz}, 1 \mathrm{H}), 3.51(\mathrm{~s}, 2 \mathrm{H}) .{ }^{13} \mathrm{C} \mathrm{NMR}\left(126 \mathrm{MHz}, \mathrm{CD}_{3} \mathrm{OD}\right) \delta$ 169.6, 164.0, 150.0, 145.5, 138.4, 136.5, 134.2, 132.8, 131.1, 129.7, 125.6, 106.3, 103.2, 94.8, 92.4, 90.9, 75.2, 52.6. ${ }^{19} \mathrm{~F}$ NMR (471 MHz, CD $\left.{ }_{3} \mathrm{OD}\right) \delta$-192.44, -192.48, -192.49, -192.52, -192.55, -192.59, -192.60, -192.64. HRMS $\left(\mathrm{ESI}^{+}\right) \mathrm{m} / \mathrm{z}$ calcd for $\mathrm{C}_{17} \mathrm{H}_{16} \mathrm{FIN}_{2} \mathrm{NaO}_{6}[\mathrm{M}+\mathrm{Na}]^{+} 512.9929$, found 512.9909.

5'-O-Benzoyl-2'-deoxy-2'-fluoro-4'-Ca-methoxyuridine (5). A solution of nucleoside 4 (2.12 g, $4.32 \mathrm{mmol})$ was prepared in $\mathrm{CH}_{2} \mathrm{Cl}_{2}(119 \mathrm{~mL})$ and $\mathrm{H}_{2} \mathrm{O}(6.8 \mathrm{~mL})$. 3-Chloroperoxybenzoic acid (mCPBA) (77\% purity, $3.88 \mathrm{~g}, 17.3 \mathrm{mmol}$ ) was added slowly to the stirring solution. The reaction was heated to $40{ }^{\circ} \mathrm{C}$ and allowed to react for $5 \mathrm{~h}$, after which the solvents were concentrated and the resulting residue was purified by column chromatography (40-60\% EtOAc/Petroleum Ether) to afford the desired product 5 as a white foam $(1.02 \mathrm{~g}, 62 \%)$. $\mathrm{R}_{\mathrm{f}}(50 \%$ EtOAc/Petroleum Ether) 0.50; ${ }^{1} \mathrm{H}$ NMR (500 MHz, Acetonitrile- $\left.d_{3}\right) \delta 9.03(\mathrm{~s}, 1 \mathrm{H}), 8.05$ (dd, $J=$ 8.4, $1.3 \mathrm{~Hz}, 2 \mathrm{H}), 7.69-7.59(\mathrm{~m}, 1 \mathrm{H}), 7.52$ (t, $J=7.8 \mathrm{~Hz}, 2 \mathrm{H}), 7.35$ (d, J=8.1 Hz, 1H), 5.82 (dd, $J=21.3,1.3 \mathrm{~Hz}, 1 \mathrm{H}), 5.48(\mathrm{dd}, J=8.1,1.8 \mathrm{~Hz}, 1 \mathrm{H}), 5.15(\mathrm{ddd}, J=54.2,6.0,1.2 \mathrm{~Hz}, 1 \mathrm{H}), 4.63$ $(\mathrm{s}, 1 \mathrm{H}), 4.47(\mathrm{~d}, J=12.1 \mathrm{~Hz}, 1 \mathrm{H}), 3.47(\mathrm{~s}, 3 \mathrm{H}), 3.38(\mathrm{dd}, J=11.5,1.6 \mathrm{~Hz}, 1 \mathrm{H}) .{ }^{13} \mathrm{C}$ NMR $(126$ $\left.\mathrm{MHz}, \mathrm{CD}_{3} \mathrm{CN}\right) \delta 163.7,150.9,143.2,134.4,130.7,130.6,129.6,105.2,103.1,93.5,92.8,92.5$, 92.1, 72.7, 72.5, 61.6, 50.3. ${ }^{19} \mathrm{~F}$ NMR (471 MHz, CD $\left.3 \mathrm{CN}\right) \delta$-193.90, -193.94, -193.99, -194.01, 194.05, -194.10. HRMS $\left(\mathrm{ESI}^{+}\right) \mathrm{m} / \mathrm{z}$ calcd for $\mathrm{C}_{17} \mathrm{H}_{17} \mathrm{FN}_{2} \mathrm{NaO}_{7}[\mathrm{M}+\mathrm{Na}]^{+}$403.0912, found 403.0908. 
2'-Deoxy-2'-fluoro-4'-Ca-methoxyuridine (6). A suspension of nucleoside 5 (1.02 g, 2.68 mmol) was prepared in methanolic ammonia $(2 \mathrm{M}, 10 \mathrm{~mL})$ and stirred overnight at room temperature. The resulting mixture was evaporated to remove solvents and then purified by column chromatography $\left(2-20 \% \mathrm{MeOH} / \mathrm{CH}_{2} \mathrm{Cl}_{2}\right)$ to afford the desired product 5 as a white foam (719 mg, 97\%). $\mathrm{R}_{\mathrm{f}}\left(20 \% \mathrm{MeOH} / \mathrm{CH}_{2} \mathrm{Cl}_{2}\right): 0.52 ;{ }^{1} \mathrm{H}$ NMR (500 MHz, CD $\left.{ }_{3} \mathrm{OD}\right) \delta 7.83$ (d, $J=8.1$ Hz, 1H), 6.04 (dd, $J=19.1,1.4 \mathrm{~Hz}, 1 \mathrm{H}), 5.68(\mathrm{~d}, J=8.1 \mathrm{~Hz}, 1 \mathrm{H}), 5.08-4.95(\mathrm{~m}, 1 \mathrm{H}), 4.54(\mathrm{dd}$, $J=22.6,5.8 \mathrm{~Hz}, 1 \mathrm{H}), 3.90(\mathrm{~d}, J=11.9 \mathrm{~Hz}, 1 \mathrm{H}), 3.65(\mathrm{~d}, J=11.9 \mathrm{~Hz}, 1 \mathrm{H}), 3.42(\mathrm{~s}, 3 \mathrm{H}) .{ }^{13} \mathrm{C} \mathrm{NMR}$ $\left(126 \mathrm{MHz}, \mathrm{CD}_{3} \mathrm{OD}\right) \delta 166.1,151.9,143.1,107.9,102.8,94.5,93.0,91.3,71.1,60.3,50.0 .{ }^{19} \mathrm{~F}$ NMR (471 MHz, CD $\left.{ }_{3} \mathrm{OD}\right) \delta$-197.93, -197.97, -197.98, -198.02, -198.05, -198.09, -198.09, 198.13. UV/vis $\left(\mathrm{H}_{2} \mathrm{O}\right): \varepsilon_{260}=9500 \mathrm{~mol}^{-1} \mathrm{dm}^{3} \mathrm{~cm}^{-1}$. HRMS $\left(\mathrm{ESI}^{+}\right) \mathrm{m} / \mathrm{z}$ calcd for $\mathrm{C}_{10} \mathrm{H}_{13} \mathrm{FN}_{2} \mathrm{NaO}_{6}$ $[\mathrm{M}+\mathrm{Na}]^{+} 299.0650$, found 299.0647.

5'-O-[Bis(4-methoxyphenyl)phenylmethyl]-2'-deoxy-2'-fluoro-4'-Ca-methoxyuridine (7). A solution of nucleoside 6 (720 mg, $2.6 \mathrm{mmol})$ was prepared in pyridine (36 mL) under argon. 4,4'dimethoxytrityl chloride $(1.24 \mathrm{~g}, 3.65 \mathrm{mmol})$ was added, and the reaction was allowed to stir for $2 \mathrm{~h}$ at $40{ }^{\circ} \mathrm{C}$. Pyridine was subsequently evaporated under vacuum, and the resulting residue was purified by column chromatography using de-acidified silica gel by treatment with $10 \%$ triethylamine in DCM and DCM washing (1-3\% $\left.\mathrm{MeOH} / \mathrm{CH}_{2} \mathrm{Cl}_{2}\right)$ to obtain compound 7 as a white foam (1.05 g, 78\%). $\mathrm{R}_{\mathrm{f}}\left(10 \% \mathrm{MeOH} / \mathrm{CH}_{2} \mathrm{Cl}_{2}\right)$ : 0.79; ${ }^{1} \mathrm{H} \mathrm{NMR}\left(500 \mathrm{MHz}, \mathrm{CD}_{3} \mathrm{OD}\right) \delta 8.53$ $(\mathrm{d}, J=4.3 \mathrm{~Hz}, 2 \mathrm{H}), 7.88-7.80(\mathrm{~m}, 2 \mathrm{H}), 7.46-7.40(\mathrm{~m}, 4 \mathrm{H}), 7.35-7.26(\mathrm{~m}, 6 \mathrm{H}), 7.25-7.21$ (m, 1H), $6.90-6.84(\mathrm{~m}, 4 \mathrm{H}), 6.01(\mathrm{dd}, J=19.3,0.9 \mathrm{~Hz}, 1 \mathrm{H}), 5.34(\mathrm{~d}, J=8.0 \mathrm{~Hz}, 1 \mathrm{H}), 5.10$ $(\mathrm{ddd}, J=54.0,5.7,0.9 \mathrm{~Hz}, 1 \mathrm{H}), 4.80(\mathrm{dd}, J=23.6,5.7 \mathrm{~Hz}, 1 \mathrm{H}), 3.78(\mathrm{~s}, 6 \mathrm{H}), 3.52(\mathrm{~d}, J=10.0$ $\mathrm{Hz}, 1 \mathrm{H}), 3.33(\mathrm{~d}, J=8.6 \mathrm{~Hz}, 1 \mathrm{H}), 3.22(\mathrm{~s}, 3 \mathrm{H}) .{ }^{13} \mathrm{C} \mathrm{NMR}\left(126 \mathrm{MHz}, \mathrm{CD}_{3} \mathrm{OD}\right) \delta 166.2,160.3$, $151.8,150.1,145.9,143.3,138.4,136.7,136.5,131.4,131.4,129.4,128.9,128.0,125.6,114.2$, 107.4, 102.8, 94.4, 92.9, 91.7, 91.4, 88.4, 72.0, 71.9, 62.1, 55.7, 49.9. ${ }^{19} \mathrm{~F}$ NMR (471 MHz, $\left.\mathrm{CD}_{3} \mathrm{OD}\right) \delta$-195.12, -195.16, -195.17, -195.21, -195.24, -195.28, -195.29, -195.33. HRMS (ESI $\left.{ }^{+}\right)$ $\mathrm{m} / \mathrm{z}$ calcd for $\mathrm{C}_{31} \mathrm{H}_{31} \mathrm{FN}_{2} \mathrm{NaO}_{8}[\mathrm{M}+\mathrm{Na}]^{+}$601.1957, found 601.1955 .

5'-O-[Bis(4-methoxyphenyl)phenylmethyl]-2'-deoxy-2'-fluoro-4'-Co-methoxyuridine, 3'-[2cyanoethyl $N, N$-bis(1-methylethyl)phosphoramidite] (8). Dimethoxytritylated nucleoside 7 (540 mg, $0.93 \mathrm{mmol}$ ), was dried under vacuum overnight and coevaporated with $\mathrm{CH}_{3} \mathrm{CN}_{\text {four }}$ times. Dry THF $(10 \mathrm{~mL})$ was added under argon. To the solution was added EtN(iPr $)_{2}(830 \mu \mathrm{L}$, 
$4.8 \mathrm{mmol}$ ) and then 2-cyanoethyl $N, N$-diisopropylchlorophosphoramidite (230 $\mu \mathrm{L}, 1.0 \mathrm{mmol})$. The reaction mixture was stirred for $7 \mathrm{~h}$ at room temperature, progress of the reaction was monitored by TLC (1:1 EtOAc, Hexanes). After completion of the reaction, the mixture was extracted using DCM and saturated sodium bicarbonate, the organic phases were collected and dried over anhydrous $\mathrm{MgSO}_{4}$, filtered and the filtrate was concentrated on silica with a small amount of $\mathrm{Et}_{3} \mathrm{~N}$ for direct loading on a deacidified silica column (40\%-70\% EtOAc in hexanes) to afford phosphoramidite 8 as a white foam (360 mg, 49\%). $\mathrm{R}_{\mathrm{f}}\left(50 \% \mathrm{EtOAc} /\right.$ hexanes) $0.34 .{ }^{1} \mathrm{H}$ NMR (400 MHz, DMSO-d6) $\delta 11.48(\mathrm{~s}, 1 \mathrm{H}), 7.83(\mathrm{dd}, J=7.9,1.8 \mathrm{~Hz}, 1 \mathrm{H}), 7.42-7.37$ (m, 2H), $7.32-7.22(\mathrm{~m}, 7 \mathrm{H}), 6.89-6.85(\mathrm{~m}, 4 \mathrm{H}), 6.00(\mathrm{dd}, J=29.8,21.6 \mathrm{~Hz}, 1 \mathrm{H}), 5.32-5.48(\mathrm{~m}, 2 \mathrm{H})$, $5.26-5.13(\mathrm{~m}, 2 \mathrm{H}), 5.06-4.80(\mathrm{~m}, 1 \mathrm{H}), 4.03(\mathrm{q}, J=7.1 \mathrm{~Hz}, 1 \mathrm{H}), 3.78-3.51(\mathrm{~m}, 10 \mathrm{H}), 3.42-$ $3.36(\mathrm{~m}, 1 \mathrm{H}), 3.21(\mathrm{~s}, 1 \mathrm{H}), 3.17(\mathrm{~s}, 2 \mathrm{H}), 3.04-3.10(\mathrm{~m}, 1 \mathrm{H}), 2.78(\mathrm{t}, J=6.0 \mathrm{~Hz}, 1 \mathrm{H}), 2.65(\mathrm{q}, J$ $=5.7 \mathrm{~Hz}, 1 \mathrm{H}) 1.99(\mathrm{~s}, 1 \mathrm{H}) .{ }^{13} \mathrm{C}$ NMR $\left(126 \mathrm{MHz}, \mathrm{DMSO}-d_{6}\right) \delta 170.3,163.2,163.1,158.2,158.1$, $150.1,144.4,144.3,142.8,142.6,135.03,134.98,134.9,129.9,129.81,129.79,127.83,127.77$, 126.8 , 119.0, 118.7, 113.13, 113.09, 106.15, 106.09, 106.03, 106.00, 101.70, 101.67, 101.62, 101.59, 91.37, 91.92, 91.1, 89.8, 86.14, 86.07, 69.7, 62.1, 61.5, 59.7, 59.0, 58.9, 58.6, 58.4, 55.0, 49.9, 49.6, 42.9, 42.8, 42.7, 42.6, 24.5, 24.43, 24.39, 24.32, 24.26, 24.2, 20.74, 19.74, 19.69, 19.6, 19.5, 14.1. ${ }^{19}$ F NMR (376 MHz, DMSO-d6) $\delta$-193.87, -193.90, -193.93, -193.96, -193.98, 194.02, -194.04, -194.08, -194.10, -194.13, -194.17, -194.23. ${ }^{31} \mathrm{P}$ NMR (202 MHz, DMSO- $d 6$ ) $\delta$ 155.40, 155.33, 155.27, 155.23. HRMS $\left(\mathrm{ESI}^{+}\right) \mathrm{m} / \mathrm{z}$ calcd for $\mathrm{C}_{40} \mathrm{H}_{48} \mathrm{FN}_{4} \mathrm{NaO}_{9} \mathrm{P}[\mathrm{M}+\mathrm{Na}]^{+}$ 801.3041, found 801.3044.

Non-Stereoselective Synthesis

4',5'-Didehydro-2',5'-dideoxy-3'-O-[(1,1-dimethylethyl)dimethylsilyl $]$-2'-fluorouridine (9).

To a solution of compound $2(230 \mathrm{mg}, 1.0 \mathrm{mmol})$ in anhydrous pyridine $(3 \mathrm{~mL})$ were added tertbutyldimethylsilyl chloride (230 mg, $1.5 \mathrm{mmol})$ and imidazole $(210 \mathrm{mg}, 3.0 \mathrm{mmol})$, and the mixture was stirred overnight at ambient temperature. After removing the solvent under reduced pressure, the residue was extracted with $\mathrm{CH}_{2} \mathrm{Cl}_{2}$ and saturated $\mathrm{NaHCO}_{3}$ aqueous solution. The organic layer was separated, dried over anhydrous $\mathrm{Na}_{2} \mathrm{SO}_{4}$, filtered and concentrated. The crude material was purified by flash silica gel column chromatography (0-50\% EtOAc in hexanes) to obtain compound 9 (300 mg, $0.88 \mathrm{mmol}, 87 \%, \mathrm{R}_{\mathrm{f}}=0.25$; developed with $33 \%$ EtOAc in hexanes). ${ }^{1} \mathrm{H}$ NMR (400 MHz, DMSO-d6) $\delta 11.52(\mathrm{~s}, 1 \mathrm{H}), 7.63(\mathrm{~d}, J=8.2 \mathrm{~Hz}, 1 \mathrm{H}), 6.05$ (dd, $J=$ 
$19.4,1.8 \mathrm{~Hz}, 1 \mathrm{H}), 5.68(\mathrm{~d}, J=8.2 \mathrm{~Hz}, 1 \mathrm{H}), 5.38(\mathrm{ddd}, J=52.8,5.0,1.8 \mathrm{~Hz}, 1 \mathrm{H}), 5.08-5.02(\mathrm{~m}$, $1 \mathrm{H}), 4.50(\mathrm{~s}, 1 \mathrm{H}), 4.20(\mathrm{~s}, 1 \mathrm{H}), 0.90(\mathrm{~s}, 9 \mathrm{H}), 0.14$ (s, 3H), 0.13 (s, 3H). ${ }^{13} \mathrm{C} \mathrm{NMR}(126 \mathrm{MHz}$, DMSO-d6) $\delta 163.1,160.8,150.2,142.0,102.3,91.0,90.5,90.2,89.5,84.6,69.1,69.0,25.6$, 17.8, -5.0, -5.2. ${ }^{19} \mathrm{~F}$ NMR (376 MHz, DMSO-d6) $\delta$-207.67, -207.72, -207.77, -207.81, -207.86, 207.91. HRMS calc. for $\mathrm{C}_{15} \mathrm{H}_{24} \mathrm{FN}_{2} \mathrm{O}_{4} \mathrm{Si}[\mathrm{M}+\mathrm{H}]^{+} 343.1489$, found 343.1491.

2'-Deoxy-3'-O-[(1,1-dimethylethyl)dimethylsilyl $]-2^{\prime}$-fluoro-4'-Ca-methoxyuridine (10)/ 2'-

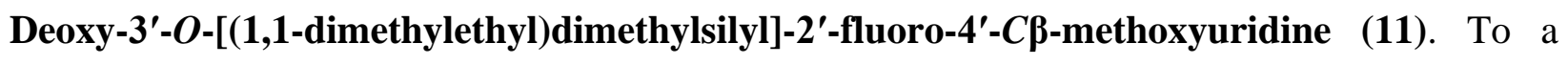
solution of compound 9 (290 mg, $0.85 \mathrm{mmol})$ in $\mathrm{MeOH}(10 \mathrm{~mL})$ was added mCPBA (390 mg, $1.7 \mathrm{mmol}$ ), and the mixture was stirred overnight at ambient temperature. After removing the solvent under reduced pressure, the residue was extracted with $\mathrm{CH}_{2} \mathrm{Cl}_{2}$ and saturated $\mathrm{NaHCO}_{3}$ aqueous solution. The organic layer was separated, dried over anhydrous $\mathrm{Na}_{2} \mathrm{SO}_{4}$, filtered and concentrated. The crude material was purified by flash silica gel column chromatography (0-5\% $\mathrm{MeOH}$ in $\left.\mathrm{CH}_{2} \mathrm{Cl}_{2}\right)$ to obtain compound 10 (170 mg, $0.45 \mathrm{mmol}, 53 \%$, $\mathrm{R}_{\mathrm{f}}=0.28$; developed with $5 \% \mathrm{MeOH}$ in $\left.\mathrm{CH}_{2} \mathrm{Cl}_{2}\right)$ and compound $11\left(60 \mathrm{mg}, 0.15 \mathrm{mmol}, 17 \%, \mathrm{R}_{\mathrm{f}}=0.31\right.$; developed with $5 \% \mathrm{MeOH}$ in $\mathrm{CH}_{2} \mathrm{Cl}_{2}$ ). Compound 10: ${ }^{1} \mathrm{H} \mathrm{NMR}\left(500 \mathrm{MHz}, \mathrm{DMSO}-d_{6}\right) \delta 11.43(\mathrm{~s}, 1 \mathrm{H}), 7.79$ (d, $J=8.0 \mathrm{~Hz}, 1 \mathrm{H}), 6.04(\mathrm{dd}, J=18.0,2.0 \mathrm{~Hz}, 1 \mathrm{H}), 5.66(\mathrm{~d}, J=8.0 \mathrm{~Hz}, 1 \mathrm{H}), 5.30(\mathrm{t}, J=5.5 \mathrm{~Hz}$, $1 \mathrm{H}), 5.12$ (ddd, $J=54.0,5.9,2.0 \mathrm{~Hz}, 1 \mathrm{H}), 4.53$ (dd, $J=20.5,6.0 \mathrm{~Hz}, 1 \mathrm{H}), 3.67$ (dd, $J=11.5,5.0$ Hz, 1H), 3.39 (dd, J = 11.8, 5.8 Hz, 1H), 3.30 (s, 3H), 0.89 (s, 9H), 0.104 (s, 3H), 0.101 (s, 3H). ${ }^{13} \mathrm{C}$ NMR (126 MHz, DMSO-d6) $\delta$ 163.2, 150.3, 141.0, 107.1, 101.9, 92.1, 90.5, 88.3, 88.0, 69.8, 69.7, 59.9, 49.84, 49.83, 25.6, 17.9, -5.0, -5.1. ${ }^{19} \mathrm{~F}$ NMR (376 MHz, DMSO-d6) $\delta ~-203.85,-$ 203.90, -203.95, -203.99, -204.04, -204.10. HRMS calc. for $\mathrm{C}_{16} \mathrm{H}_{27} \mathrm{FN}_{2} \mathrm{NaO}_{6} \mathrm{Si}[\mathrm{M}+\mathrm{H}]^{+}$ 413.1520, found 413.1531. Compound 11: ${ }^{1} \mathrm{H}$ NMR (400 MHz, DMSO-d6) $\delta 11.51(\mathrm{~d}, J=2.4$ $\mathrm{Hz}, 1 \mathrm{H}), 7.45$ (d, $J=8.0 \mathrm{~Hz}, 1 \mathrm{H}), 6.25$ (dd, $J=14.4,6.8 \mathrm{~Hz}, 1 \mathrm{H}), 5.81$ (dd, $J=8.0,2.0 \mathrm{~Hz}, 1 \mathrm{H})$, 5.55 (ddd, $J=51.8,6.8,4.2 \mathrm{~Hz}, 1 \mathrm{H}), 4.86$ (brs, $1 \mathrm{H}), 4.25$ (d, $J=4.0 \mathrm{~Hz}, 1 \mathrm{H}), 3.59$ (s, 2H), 3.28 $(\mathrm{s}, 3 \mathrm{H}), 0.91$ (s, 9H), 0.13 (s, 3H), 0.10 (s, 3H). ${ }^{13} \mathrm{C}$ NMR (101 MHz, DMSO-d6) $\delta ~ 166.1,162.7$, 151.0, 140.0, 133.3, 132.5, 130.6, 128.8, 127.9, 110.3, 110.2, 103.6, 92.9, 91.0, 84.9, 84.6, 73.2, 73.1, 55.4, 49.0, 25.6, 18.0, -4.9, -5.0, -5.3. ${ }^{19} \mathrm{~F}$ NMR (376 MHz, DMSO-d6) $\delta ~-220.62,-220.65$, 220.75, -220.79. HRMS calc. for $\mathrm{C}_{16} \mathrm{H}_{27} \mathrm{FN}_{2} \mathrm{NaO}_{6} \mathrm{Si}[\mathrm{M}+\mathrm{H}]^{+} 413.1520$, found 413.1538 .

$5^{\prime}$ - $O$-[bis(4-methoxyphenyl)phenylmethyl]-2'-deoxy-3'-O-[(1,1-

dimethylethyl)dimethylsilyl]-2'-fluoro-4'-Ca-methoxyuridine (12). To a solution of 
compound 10 (170 mg, $0.42 \mathrm{mmol})$ in anhydrous pyridine $(2 \mathrm{~mL})$ was added DMTr-Cl $(220 \mathrm{mg}$, $0.64 \mathrm{mmol}$ ) at $0{ }^{\circ} \mathrm{C}$. The reaction mixture was stirred at ambient temperature for $14 \mathrm{~h}$ then quenched by addition of $\mathrm{MeOH}(0.2 \mathrm{~mL})$. The solvent was removed under reduced pressure, and the residue was extracted with $\mathrm{CH}_{2} \mathrm{Cl}_{2}$ and saturated $\mathrm{NaHCO}_{3}$ aqueous solution. The organic layer was separated, dried over anhydrous $\mathrm{Na}_{2} \mathrm{SO}_{4}$, filtered and concentrated. The crude material was purified by flash silica gel column chromatography (0-50\% EtOAc in hexanes) to obtain compound 12 (260 mg, $0.38 \mathrm{mmol}, 89 \%, \mathrm{R}_{\mathrm{f}}=0.27$; developed with $33 \%$ EtOAc in hexanes). ${ }^{1} \mathrm{H}$ NMR (400 MHz, DMSO-d6) $\delta 11.50(\mathrm{~s}, 1 \mathrm{H}), 7.86$ (d, $J=8.4 \mathrm{~Hz}, 1 \mathrm{H}), 7.38-7.22(\mathrm{~m}, 9 \mathrm{H}), 6.87$ $(\mathrm{dd}, J=8.8,1.6 \mathrm{~Hz}, 4 \mathrm{H}), 6.02$ (d, $J=20.8 \mathrm{~Hz}, 1 \mathrm{H}), 5.42$ (d, $J=8.0 \mathrm{~Hz}, 1 \mathrm{H}), 5.29$ (dd, $J=54.8$, $5.6 \mathrm{~Hz}, 1 \mathrm{H}), 4.81(\mathrm{dd}, J=23.6,5.6 \mathrm{~Hz}, 1 \mathrm{H}), 3.73(\mathrm{~s}, 6 \mathrm{H}), 3.44(\mathrm{~d}, J=10.0 \mathrm{~Hz}, 1 \mathrm{H}), 3.18(\mathrm{~s}, 3 \mathrm{H})$, $2.92(\mathrm{~d}, J=10.0 \mathrm{~Hz}, 1 \mathrm{H}), 0.77(\mathrm{~s}, 9 \mathrm{H}), 0.029(\mathrm{~s}, 3 \mathrm{H}),-0.061(\mathrm{~s}, 3 \mathrm{H}) .{ }^{13} \mathrm{C} \mathrm{NMR}(126 \mathrm{MHz}$, DMSO-d6) $\delta 163.2,158.2,158.2,150.1,144.2,142.3,135.0,134.8,129.8,127.8,127.8,126.8$, $113.2,113.1,105.9,101.6,91.6,90.3,90.0,86.1,70.5,70.3,61.2,55.0,55.0,49.7,25.5,17.7$, 4.9, -5.3. ${ }^{19} \mathrm{~F}$ NMR (376 MHz, DMSO- $\left.d 6\right) \delta-196.90,-196.96,-197.02,-197.05,-197.11$, 197.16. HRMS calc. for $\mathrm{C}_{37} \mathrm{H}_{45} \mathrm{FN}_{2} \mathrm{NaO}_{8} \mathrm{Si}[\mathrm{M}+\mathrm{Na}]^{+}$715.2827, found 715.2833.

\section{5'-O-[bis(4-methoxyphenyl)phenylmethyl]-2'-deoxy-3'-O-[(1,1-}

dimethylethyl)dimethylsilyl]-2'-fluoro-4' $-\boldsymbol{C \beta}$-methoxyuridine (13). To a solution of compound 11 (1.30 g, $3.3 \mathrm{mmol})$ in anhydrous pyridine $(16.5 \mathrm{~mL})$ was added DMTr-Cl $(3.89 \mathrm{~g}$, $9.99 \mathrm{mmol})$ at $0{ }^{\circ} \mathrm{C}$. The reaction mixture was stirred overnight at ambient temperature then quenched by addition of $\mathrm{MeOH}(2 \mathrm{~mL})$. The solvent was removed under reduced pressure, and the residue was extracted with $\mathrm{CH}_{2} \mathrm{Cl}_{2}$ and saturated $\mathrm{NaHCO}_{3}$ aqueous solution. The organic layer was separated, dried over anhydrous $\mathrm{Na}_{2} \mathrm{SO}_{4}$, filtered and concentrated. The crude material was purified by flash silica gel column chromatography (0-50\% EtOAc in hexanes) to obtain compound 13 (2.05 g, $2.96 \mathrm{mmol}, 89 \%, \mathrm{R}_{\mathrm{f}}=0.27$; developed with 33\% EtOAc in hexanes). ${ }^{1} \mathrm{H}$ NMR (400 MHz, DMSO-d6) $\delta 11.55$ (s, 1H), 7.61 (d, J=8.0 Hz, 1H), $7.43-7.40$ (m, 2H), 7.33 - $7.20(\mathrm{~m}, 7 \mathrm{H}), 6.90-6.87(\mathrm{~m}, 4 \mathrm{H}), 6.22(\mathrm{dd}, J=15.2,4.8 \mathrm{~Hz}, 1 \mathrm{H}), 5.79(\mathrm{~d}, J=8.0 \mathrm{~Hz}, 1 \mathrm{H})$, $5.44(\mathrm{dt}, J=52.0,4.6 \mathrm{~Hz}, 1 \mathrm{H}), 4.37(\mathrm{dd}, J=8.2,4.6 \mathrm{~Hz}, 1 \mathrm{H}), 3.73$ (s, 6H), 3.47 (d, $J=10.8 \mathrm{~Hz}$, 1H), 3.27 (s, 3H), $3.00(\mathrm{~d}, J=10.4 \mathrm{~Hz}, 1 \mathrm{H}), 0.70(\mathrm{~s}, 9 \mathrm{H}), 0.012$ (d, $J=1.6 \mathrm{~Hz}, 3 \mathrm{H}),-0.096$ (s, $3 \mathrm{H}) .{ }^{13} \mathrm{C}$ NMR (126 MHz, DMSO-d6) $\delta$ 162.9, 158.1, 150.7, 144.5, 140.4, 135.3, 135.0, 129.8, 127.8, 127.7, 126.7, 113.2, 113.1, 108.7, 108.6, 103.0, 92.2, 90.6, 86.6, 86.3, 85.9, 73.8, 73.7, 62.7, 55.0, 51.4, 25.4, 17.6, -4.90, -4.92, -5.3. ${ }^{19} \mathrm{~F}$ NMR (376 MHz, DMSO-d6) $\delta-215.23$, - 
215.26, -215.29, -215.37, -215.41, -215.43. HRMS calc. for $\mathrm{C}_{37} \mathrm{H}_{45} \mathrm{FN}_{2} \mathrm{NaO}_{8} \mathrm{Si}[\mathrm{M}+\mathrm{Na}]^{+}$ 715.2827 , found 715.2855 .

5'-O-[Bis(4-methoxyphenyl)phenylmethyl]-2'-deoxy-2'-fluoro-4'-Ca-methoxyuridine

Compound 12 (7.10 g, $10.2 \mathrm{mmol})$ was treated with $1 \mathrm{M} n$-TBAF (16 mL, $16 \mathrm{mmol})$ in THF (50 $\mathrm{mL}$ ) at ambient temperature for $2 \mathrm{~h}$. The solvent was removed and the residue was purified by flash silica gel column chromatography (33-80\% EtOAc in hexanes) to obtain compound 7 (4.0 $\mathrm{g}, 6.9 \mathrm{mmol}, 68 \%, \mathrm{R}_{\mathrm{f}}=0.18$; developed with 50\% EtOAc in hexanes). ${ }^{1} \mathrm{H}$ NMR (400 MHz, DMSO- $\left.d_{6}\right) \delta 11.48(\mathrm{~s}, 1 \mathrm{H}), 7.76(\mathrm{~d}, J=8.0 \mathrm{~Hz}, 1 \mathrm{H}), 7.40(\mathrm{~d}, J=7.6 \mathrm{~Hz}, 2 \mathrm{H}), 7.34-7.24(\mathrm{~m}$, $7 \mathrm{H}), 6.90(\mathrm{~d}, J=8.0 \mathrm{~Hz}, 4 \mathrm{H}), 5.95(\mathrm{~d}, J=20.8 \mathrm{~Hz}, 1 \mathrm{H}), 5.40(\mathrm{~d}, J=8.0 \mathrm{~Hz}, 1 \mathrm{H}), 5.28(\mathrm{~d}, J=$ $10.0 \mathrm{~Hz}, 1 \mathrm{H}), 5.19$ (d, $J=55.8 \mathrm{~Hz}, 6.0 \mathrm{H}, 1 \mathrm{H}), 4.66$ (ddd, $J=24.8,10.0,6.0 \mathrm{~Hz}, 1 \mathrm{H}), 3.74$ (s, $6 \mathrm{H}), 3.30(\mathrm{~d}, J=10.0 \mathrm{~Hz}, 1 \mathrm{H}), 3.14(\mathrm{~s}, 3 \mathrm{H}), 3.09$ (d, $J=10.0 \mathrm{~Hz}, 1 \mathrm{H}) .{ }^{13} \mathrm{C}$ NMR $(126 \mathrm{MHz}$, DMSO- $d 6) \delta 163.1,158.2,158.1,150.0,144.5,142.1,135.1,135.0,129.8,129.8,127.9,127.7$, 126.8, 113.2, 113.2, 105.4, 101.7, 92.7, 91.2, 89.9, 89.6, 86.0, 70.7, 70.5, 61.2, 55.0, 49.1. ${ }^{19} \mathrm{~F}$ NMR (376 MHz, DMSO- $d_{6}$ ) $\delta-196.30,-196.37,-196.43,-196.45,-196.51,-196.57$. HRMS calc. for $\mathrm{C}_{31} \mathrm{H}_{31} \mathrm{FN}_{2} \mathrm{NaO}_{8}[\mathrm{M}+\mathrm{Na}]^{+}$601.1962, found 601.1953 .

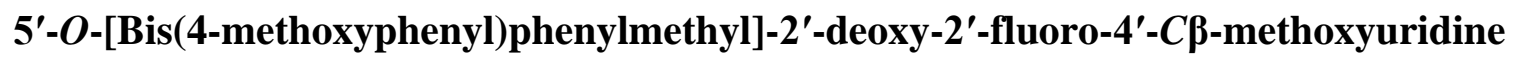

(14). Compound 13 (2.05 g, $2.96 \mathrm{mmol})$ was treated with $1 \mathrm{M} n$-TBAF $(6.0 \mathrm{~mL}, 6.0 \mathrm{mmol})$ in THF $(10 \mathrm{~mL})$ overnight at ambient temperature. The solvent was removed and the residue was purified by flash silica gel column chromatography (33-80\% EtOAc in hexanes) to obtain compound 14 (1.04 g, $1.80 \mathrm{mmol}, 61 \%, \mathrm{R}_{\mathrm{f}}=0.14$; developed with 50\% EtOAc in hexanes). ${ }^{1} \mathrm{H}$ NMR (400 MHz, DMSO-d6) $\delta 11.50$ (s, 1H), $7.47-7.44$ (m, 2H), 7.40 (d, $J=8.4$ Hz, 1H), 7.34 $-7.28(\mathrm{~m}, 6 \mathrm{H}), 7.25-7.21(\mathrm{~m}, 1 \mathrm{H}), 6.91-6.87(\mathrm{~m}, 4 \mathrm{H}), 6.39(\mathrm{~d}, J=5.6 \mathrm{~Hz}, 1 \mathrm{H}), 6.28(\mathrm{dd}, J=$ 14.6, $6.6 \mathrm{~Hz}, 1 \mathrm{H}), 5.76$ (d, $J=8.0 \mathrm{~Hz}, 1 \mathrm{H}), 5.57$ (ddd, $J=52.2,6.6,4.6 \mathrm{~Hz}, 1 \mathrm{H}), 4.36$ (dd, $J=$ 5.8, 4.2 Hz, 1H), 3.74 (s, 3H), 3.73 (s, 3H), 3.48 (d, $J=10.0 \mathrm{~Hz}, 1 \mathrm{H}), 2.90-2.89$ (m, 1H), 2.87 (s, 3H). ${ }^{13} \mathrm{C}$ NMR (126 MHz, DMSO- $\left.d_{6}\right) \delta 162.7,158.2,150.9,144.5,139.9,135.3,134.8$, 129.9, 129.8, 127.8, 126.7, 113.1, 113.1, 109.6, 109.6, 103.5, 93.1, 91.6, 85.5, 84.9, 84.7, 72.1, 72.0, 57.1, 55.0, 48.5. ${ }^{19} \mathrm{~F}$ NMR (376 MHz, DMSO- $\left.d_{6}\right) \delta-221.72,-221.76,-221.86,-221.90$. HRMS calc. for $\mathrm{C}_{31} \mathrm{H}_{31} \mathrm{FN}_{2} \mathrm{NaO} 8[\mathrm{M}+\mathrm{Na}]^{+}$601.1962, found 601.1987 .

5'-O-[bis(4-methoxyphenyl)phenylmethyl]-2'-deoxy-2'-fluoro-4'-Ca-methoxyuridine, 3'-[2cyanoethyl $N, N$-bis(1-methylethyl)phosphoramidite] (8). To a solution of compound 7 (3.50 
g, $1.55 \mathrm{mmol})$ in anhydrous $\mathrm{CH}_{2} \mathrm{Cl}_{2}(50 \mathrm{~mL})$ and $N, N$-diisopropylethylamine $(3.17 \mathrm{~mL}, 18.2$ mmol) was added 2-cyanoethyl $N, N$-diisopropylchlorophosphoramidite ( $3.0 \mathrm{~mL}, 13 \mathrm{mmol})$. The reaction mixture was stirred at ambient temperature for $16 \mathrm{~h}$ under argon atmosphere. The reaction mixture was diluted with $\mathrm{CH}_{2} \mathrm{Cl}_{2}(200 \mathrm{~mL})$ then washed with saturated aq. $\mathrm{NaHCO}_{3}$ $(100 \mathrm{~mL})$. The organic layer was separated, dried over anhydrous $\mathrm{Na}_{2} \mathrm{SO}_{4}$, filtered and concentrated. The crude material was purified by flash silica gel column chromatography (33$50 \%$ EtOAc in hexanes) to obtain 8 (4.05 g, $5.20 \mathrm{mmol}, 86 \%, \mathrm{R}_{\mathrm{f}}=0.34,0.25$ developed with $50 \%$ EtOAc in hexanes) as a white foam. ${ }^{1} \mathrm{H}$ NMR (400 MHz, DMSO- $\left.d_{6}\right) \delta 11.48(\mathrm{~s}, 1 \mathrm{H}), 7.83$ $(\mathrm{dd}, J=8.0,1.6 \mathrm{~Hz}, 1 \mathrm{H}), 7.42-7.22(\mathrm{~m}, 9 \mathrm{H}), 6.89-6.85(\mathrm{~m}, 4 \mathrm{H}), 6.04(\mathrm{~d}, J=21.6 \mathrm{~Hz}, 0.5 \mathrm{H})$, $5.96(\mathrm{~d}, J=21.6 \mathrm{~Hz}, 0.5 \mathrm{H}), 5.48-5.32(\mathrm{~m}, 2 \mathrm{H}), 5.01(\mathrm{ddd}, J=23.8,11.9,5.9 \mathrm{~Hz}, 0.5 \mathrm{H}), 4.84$ (ddd, $J=23.0,9.5,5.9 \mathrm{~Hz}, 0.5 \mathrm{H}), 3.74(\mathrm{~s}, 3 \mathrm{H}), 3.73(\mathrm{~s}, 3 \mathrm{H}), 3.63-3.49(\mathrm{~m}, 3 \mathrm{H}), 3.39(\mathrm{dd}, J=$ 14.0, $10.0 \mathrm{~Hz}, 1 \mathrm{H}), 3.21(\mathrm{~s}, 1.5 \mathrm{H}), 3.17(\mathrm{~s}, 1.5 \mathrm{H}), 3.07(\mathrm{dd}, J=15.4,10.1 \mathrm{~Hz}, 1 \mathrm{H}), 2.78(\mathrm{t}, J=$ $6.0 \mathrm{~Hz}, 1 \mathrm{H}), 2.65(\mathrm{q}, J=5.6 \mathrm{~Hz}, 1 \mathrm{H}), 1.19-0.97(\mathrm{~m}, 12 \mathrm{H}) .{ }^{13} \mathrm{C}$ NMR $\left(126 \mathrm{MHz}, \mathrm{DMSO}-d_{6}\right) \delta$ 170.3, 163.2, 163.1, 158.2, 158.1, 150.1, 144.4, 144.3, 142.9, 142.6, 135.0, 135.0, 134.9, 129.9, $129.81,129.79,127.83,127.77,126.8,119.0,118.7,113.1,113.1,106.2,106.1,106.03,106.00$, 101.70, 101.67, 101.62, 101.59, 91.8, 91.4, 91.3, 91.1, 90.7, 90.3, 89.8, 86.1, 86.1, 71.0, 70.9, 69.9, 69.7, 69.6, 62.1, 61.5, 59.7, 59.0, 58.9, 58.6, 58.4, 55.0, 49.9, 49.6, 42.9, 42.8, 42.7, 42.6, 24.5, 24.43, 24.39, 24.32, 24.26, 24.21, 20.7, 19.74, 19.69, 19.59, 19.54, 14.1. ${ }^{19} \mathrm{~F}$ NMR (376 MHz, DMSO- $\left.d_{6}\right) \delta-193.87,-193.90,-193.93,-193.96,-193.98,-194.02,-194.04,-194.08,-$ 194.10, -194.13, -194.17, -194.23. ${ }^{31} \mathrm{P}$ NMR (162 MHz, DMSO-d6) $\delta$ 155.40, 155.33, 155.27, 155.23. HRMS calc. for $\mathrm{C}_{40} \mathrm{H}_{48} \mathrm{FN}_{4} \mathrm{NaO}_{9} \mathrm{P}[\mathrm{M}+\mathrm{Na}]^{+}$801.3041, found 801.3024.

5'-O-[bis(4-methoxyphenyl)phenylmethyl]-2'-deoxy-2'-fluoro-4'-CB-methoxyuridine, 3'-[2cyanoethyl $N, N$-bis(1-methylethyl)phosphoramidite (15). To a solution of compound 14 (1.10 g, $1.90 \mathrm{mmol})$ in anhydrous $\mathrm{CH}_{2} \mathrm{Cl}_{2}(10 \mathrm{~mL})$ and $N, N$-diisopropylethylamine $(990 \mu \mathrm{L}, 5.7 \mathrm{mmol})$ was added 2-cyanoethyl $N, N$-diisopropylchlorophosphoramidite $(890 \mu \mathrm{L}, 3.8 \mathrm{mmol})$. The reaction mixture was stirred at ambient temperature for $16 \mathrm{~h}$ under argon atmosphere. The reaction mixture was diluted with $\mathrm{CH}_{2} \mathrm{Cl}_{2}(100 \mathrm{~mL})$ then washed with saturated aq. $\mathrm{NaHCO}_{3}$ (50 $\mathrm{mL}$ ). The organic layer was separated, dried over anhydrous $\mathrm{Na}_{2} \mathrm{SO}_{4}$, filtered and concentrated. The crude material was purified by flash silica gel column chromatography (33-50\% EtOAc in hexanes) to obtain 15 (600 mg, $0.77 \mathrm{mmol}, 41 \%, \mathrm{R}_{\mathrm{f}}=0.29,0.23$ developed with 50\% EtOAc in hexanes) as a white foam. ${ }^{1} \mathrm{H}$ NMR $\left(400 \mathrm{MHz}, \mathrm{CD}_{3} \mathrm{CN}\right) \delta 9.21$ (brs, 1H), $7.52-7.49$ (m, 2H), 
$7.45(\mathrm{~d}, J=8.0 \mathrm{~Hz}, 1 \mathrm{H}), 7.40-7.35(\mathrm{~m}, 4 \mathrm{H}), 7.34-7.29(\mathrm{~m}, 2 \mathrm{H}), 7.26-7.21(\mathrm{~m}, 1 \mathrm{H}), 6.89-$ $6.87(\mathrm{~m}, 1 \mathrm{H}), 6.25(\mathrm{dd}, J=14.6,5.4 \mathrm{~Hz}, 1 \mathrm{H}), 5.73(\mathrm{~d}, J=8.0 \mathrm{~Hz}, 1 \mathrm{H}), 5.46(\mathrm{dd}, J=5.4,4.2 \mathrm{~Hz}$, $0.5 \mathrm{H}), 5.33(\mathrm{dd}, J=5.4,4.6 \mathrm{~Hz}, 0.5 \mathrm{H}), 4.51(\mathrm{ddd}, J=11.6,5.3,4.3 \mathrm{~Hz}, 1 \mathrm{H}), 3.76(\mathrm{~s}, 6 \mathrm{H}), 3.74-$ $3.36(\mathrm{~m}, 6 \mathrm{H}), 3.13(\mathrm{~s}, 3 \mathrm{H}), 2.44-2.34(\mathrm{~m}, 2 \mathrm{H}), 1.26-1.19(\mathrm{~m}, 2 \mathrm{H}), 1.26-1.07(\mathrm{~m}, 14 \mathrm{H}) .{ }^{13} \mathrm{C}$ NMR (126 MHz, CD $\left.{ }_{3} \mathrm{CN}\right) \delta$ 163.7, 159.73, 159.72, 151.7, 145.9, 141.1, 136.6, 136.40, 131.3, 131.2, 129.2, 128.8, 127.9, 119.2, 114.1, 114.0, 110.4, 110.32, 110.29, 104.1, 93.91, 93.90, 92.37, 92.35, 87.5, 87.4, 87.2, 75.8, 75.6, 75.5, 62.0, 59.5, 59.3, 55.9, 51.7, 44.2, 44.1, 24.9, 24.83, 24.80, 24.77, 20.82, 20.76. ${ }^{19} \mathrm{~F}$ NMR (376 MHz, CD $\left.3 \mathrm{CN}\right) \delta$-215.78, -215.83, -215.90, 215.92, -215.94, -215.95, -215.97, -216.04, -216.09. ${ }^{31} \mathrm{P}$ NMR (202 MHz, CD $\left.3 \mathrm{CN}\right) \delta 153.77$, 153.56, 152.46, 152.39. HRMS calc. for $\mathrm{C}_{40} \mathrm{H}_{48} \mathrm{FN}_{4} \mathrm{NaO}_{9} \mathrm{P}[\mathrm{M}+\mathrm{Na}]^{+} 801.3041$, found 801.3066.

Synthesis of solid support 16. To a solution of 7 (500 mg, $0.86 \mathrm{mmol})$ in anhydrous $\mathrm{CH}_{2} \mathrm{Cl}_{2}(10$ $\mathrm{mL}$ ) were added DMAP (320 mg, $2.6 \mathrm{mmol})$ and succinic anhydride (170 mg, $1.7 \mathrm{mmol})$. The reaction mixture was stirred for $23 \mathrm{~h}$ at ambient temperature. After removing the solvent under reduced pressure, the residue was passed through a short silica gel column (eluent: $\left.\mathrm{CH}_{2} \mathrm{Cl}_{2} / \mathrm{MeOH} / \mathrm{Et}_{3} \mathrm{~N}, 90 / 5 / 5\right)$ to obtain the succinate as the corresponding triethylammonium salt to a solution of the succinate $(630 \mathrm{mg}, 0.81 \mathrm{mmol})$ in anhydrous DMF $(50 \mathrm{~mL})$ were added HBTU (370 mg, $0.97 \mathrm{mmol})$ and DIPEA (710 $\mu \mathrm{L}, 4.1 \mathrm{mmol})$. The mixture was shaken for $5 \mathrm{~min}$ followed by addition of $8.9 \mathrm{~g}$ of long chain alkyl amino controlled pore glass support (CPG-510 $\AA$, $\mathrm{NH}_{2}$ loading: $131 \mu \mathrm{mol} / \mathrm{g}$ ). The mixture was gently shaken for $24 \mathrm{~h}$. The CPG was filtered and washed with $\mathrm{CH}_{2} \mathrm{Cl}_{2}, 20 \% \mathrm{MeOH} / \mathrm{CH}_{2} \mathrm{Cl}_{2}$, then diethyl ether. After drying in vacuo the CPG was gently shaken with acetic anhydride $(15 \mathrm{~mL})$ in anhydrous pyridine $(45 \mathrm{~mL})$ in the presence of $\mathrm{Et}_{3} \mathrm{~N}$ ( $3 \mathrm{~mL}$ ) for $3 \mathrm{~h}$ to cap all unreacted amines. The capped CPG was filtered and washed with the same solvents as described above to obtain solid support 16 (loading: $71 \mu \mathrm{mol} / \mathrm{g}$ ).

Synthesis of solid support 17. To a solution of $14(540 \mathrm{mg}, 0.93 \mathrm{mmol})$ in anhydrous $\mathrm{CH}_{2} \mathrm{Cl}_{2}$ $(10 \mathrm{~mL})$ and THF (3 mL) were added DMAP (340 mg, $2.8 \mathrm{mmol})$ and succinic anhydride (190 $\mathrm{mg}, 1.9 \mathrm{mmol})$. The reaction mixture was stirred for $23 \mathrm{~h}$ at ambient temperature. After removing the solvent under reduced pressure, the residue was passed through a short silica gel column (eluent: $\left.\mathrm{CH}_{2} \mathrm{Cl}_{2} / \mathrm{MeOH} / \mathrm{Et}_{3} \mathrm{~N}, 90 / 5 / 5\right)$ to obtain the succinate as the corresponding triethylammonium salt. To a solution of the succinate $(690 \mathrm{mg}, 0.86 \mathrm{mmol})$ in anhydrous DMF (45 mL) were added HBTU (360 mg, $0.95 \mathrm{mmol})$ and DIPEA (750 $\mu \mathrm{L}, 4.3 \mathrm{mmol})$. The mixture 
was shaken for 5 min followed by addition of $10.5 \mathrm{~g}$ of long chain alkyl amino controlled pore glass support (CPG-510 $\mathrm{A}, \mathrm{NH}_{2}$ loading: $135 \mu \mathrm{mol} / \mathrm{g}$ ). The mixture was gently shaken for $24 \mathrm{~h}$. The CPG was filtered and washed with $\mathrm{CH}_{2} \mathrm{Cl}_{2}, 20 \% \mathrm{MeOH} / \mathrm{CH}_{2} \mathrm{Cl}_{2}$, then diethyl ether. After drying in vacuo the CPG was gently shaken with acetic anhydride $(20 \mathrm{~mL})$ in anhydrous pyridine $(60 \mathrm{~mL})$ in the presence of $\mathrm{Et}_{3} \mathrm{~N}(4 \mathrm{~mL})$ for $3 \mathrm{~h}$ to cap all unreacted amines. The capped CPG was filtered and washed with the same solvents as described above to obtain solid support $\mathbf{1 7}$ (loading: $76 \mu \mathrm{mol} / \mathrm{g}$ ).

2'-Deoxy-2'-fluoro-4'-Ca-methoxyuridine (6). Compound 7 (150 $\mathrm{mg}, 0.26 \mathrm{mmol})$ was treated in $80 \% \mathrm{AcOH}(10 \mathrm{~mL})$ overnight. After removing the solvent, the residue was purified by flash silica gel column chromatography $\left(0-10 \% \mathrm{MeOH}\right.$ in $\left.\mathrm{CH}_{2} \mathrm{Cl}_{2}\right)$ to obtain $6(60 \mathrm{mg}, 0.2 \mathrm{mmol}$, $84 \%)$ as a white solid. ${ }^{1} \mathrm{H}$ NMR $\left(400 \mathrm{MHz}, \mathrm{DMSO}-d_{6}\right) \delta 11.44(\mathrm{~s}, 1 \mathrm{H}), 7.78(\mathrm{~d}, J=8.0 \mathrm{~Hz}, 1 \mathrm{H})$, $6.00(\mathrm{dd}, J=19.0,1.4 \mathrm{~Hz}, 1 \mathrm{H}), 5.64(\mathrm{~d}, J=8.0 \mathrm{~Hz}, 1 \mathrm{H}), 5.32$ (brs, $1 \mathrm{H}), 5.25(\mathrm{~d}, J=9.2 \mathrm{~Hz}, 1 \mathrm{H})$, $5.04(\mathrm{ddd}, J=54.2,5.7,1.3 \mathrm{~Hz}, 1 \mathrm{H}), 4.38-4.28(\mathrm{~m}, 1 \mathrm{H}), 3.73(\mathrm{~d}, J=11.8 \mathrm{~Hz}, 1 \mathrm{H}), 3.45(\mathrm{~d}, J=$ $11.8 \mathrm{~Hz}, 1 \mathrm{H}), 3.28$ (s, $3 \mathrm{H}) .{ }^{13} \mathrm{C}$ NMR $\left(126 \mathrm{MHz}, \mathrm{DMSO}-d_{6}\right) \delta 163.2,150.2,140.8,106.7,101.8$, 93.2, 91.7, 88.3, 88.0, 68.9, 68.8, 58.9, 49.4. ${ }^{19} \mathrm{~F}$ NMR (376 MHz, DMSO- $d_{6}$ ) $\delta-202.46,-202.51$, $-202.52,-202.57,-202.60,-202.65,-202.67,-202.72$. HRMS calc. for $\mathrm{C}_{10} \mathrm{H}_{13} \mathrm{FN}_{2} \mathrm{NaO}_{6}[\mathrm{M}+$ $\mathrm{Na}]^{+} 299.0655$, found 299.0669 .

2'-Deoxy-2'-fluoro-4'-C $\boldsymbol{\beta}$-methoxyuridine (18). Compound $\mathbf{1 4}(150 \mathrm{mg}, 0.26 \mathrm{mmol})$ was treated in $80 \% \mathrm{AcOH}(10 \mathrm{~mL})$ overnight. After removing the solvent, the residue was purified by flash silica gel column chromatography $\left(0-10 \% \mathrm{MeOH}\right.$ in $\left.\mathrm{CH}_{2} \mathrm{Cl}_{2}\right)$ to obtain 18 (50 $\mathrm{mg}, 0.2$ mmol, 70\%) as a white solid. ${ }^{1} \mathrm{H}$ NMR (400 MHz, DMSO-d $\left.d\right) \delta 11.50(\mathrm{~s}, 1 \mathrm{H}), 7.44(\mathrm{~d}, J=8.4$ $\mathrm{Hz}, 1 \mathrm{H}), 6.30(\mathrm{dd}, J=14.8,6.4 \mathrm{~Hz}, 1 \mathrm{H}), 6.06(\mathrm{~d}, J=5.2 \mathrm{~Hz}, 1 \mathrm{H}), 5.80(\mathrm{~d}, J=8.0 \mathrm{~Hz}, 1 \mathrm{H}), 5.49$ (ddd, $J=52.0,6.4,4.4 \mathrm{~Hz}, 1 \mathrm{H}), 4.84(\mathrm{t}, J=5.0 \mathrm{~Hz}, 1 \mathrm{H}), 4.09(\mathrm{t}, J=4.8 \mathrm{~Hz}, 1 \mathrm{H}), 3.70-3.66(\mathrm{~m}$, $1 \mathrm{H}), 3.56-3.51(\mathrm{~m}, 1 \mathrm{H}), 3.26(\mathrm{~s}, 3 \mathrm{H}) .{ }^{13} \mathrm{C}$ NMR (126 MHz, DMSO- $\left.d_{6}\right) \delta 162.8,151.0,140.1$, $110.4,110.3,103.5,93.3,91.8,85.1,84.9,71.5,71.4,55.6,49.0 .{ }^{19} \mathrm{~F}$ NMR (376 MHz, DMSO$\left.d_{6}\right) \delta$-221.87, -221.91, -222.01, -222.05. UV/vis $\left(\mathrm{H}_{2} \mathrm{O}\right): \varepsilon 260=9600 \mathrm{~mol}^{-1} \mathrm{dm}^{3} \mathrm{~cm}^{-1}$. HRMS calc. for $\mathrm{C}_{10} \mathrm{H}_{13} \mathrm{FN}_{2} \mathrm{NaO}_{6}[\mathrm{M}+\mathrm{Na}]^{+} 299.0655$, found 299.0659 .

Solid-Phase ON Synthesis 
General Procedures. Oligonucleotides were synthesized on an ABI 3400 DNA synthesizer at the $1 \mu \mathrm{mol}$ scale using UnyLinker ${ }^{\mathrm{TM}} \mathrm{CPG}$ as solid support, mesh $500 \AA$ with $30.1 \mu \mathrm{mol} / \mathrm{mg}$ loading. DNA phosphoramidites were prepared as $0.1 \mathrm{M}$ solutions in acetonitrile, RNA phosphoramidites, and phosphoramidite 8 and 15 as $0.1 \mathrm{M}$ solutions in acetonitrile. $0.25 \mathrm{M} \mathrm{5-}$ Ethylthiotetrazole was used as activator, $3 \%$ trichloroacetic acid in dichloromethane was used to deblock DMTr groups, acetic anhydride in tetrahydrofuran (THF) and $16 \% \mathrm{~N}$-methylimidazole in THF werr used to cap $5^{\prime}-\mathrm{OH}$ groups of failure sequences, and $0.1 \mathrm{M} \mathrm{I}_{2}$ in 1:2:10 pyridine/water/THF was used for oxidation of phosphite triester linkages. DNA monomers were coupled for $200 \mathrm{~s}$ ( $300 \mathrm{~s}$ for $\mathrm{dG}$ ); all other phosphoramidites were coupled for $600 \mathrm{~s}$ (900 s for rG). 4'-C $\alpha$-OMe-2'-F U phosphoramidite 8 was coupled for 1200 s. Deprotection and cleavage from the solid support for DNA oligonucleotides was achieved by incubating the solid supports with concentrated aqueous ammonia for $48 \mathrm{~h}$ at room temperature. After decanting, the deprotection solution was removed under vacuum in a SpeedVac lyophilizer. For RNAcontaining oligonucleotides, deprotection and cleavage from the solid support was achieved with 3:1 aqueous ammonia/EtOH for $48 \mathrm{~h}$ at room temperature, and desilylation was achieved in neat Et $3 \mathrm{NH}-3 \mathrm{HF}(150 \mu \mathrm{L})$ with shaking at room temperature for $48 \mathrm{~h}$. Purifications were performed by HPLC, using a Protein Pak DEAE 5PW analytical anionexchange column. A stationary phase of Milli-Q water and a mobile phase of $1 \mathrm{M} \mathrm{LiClO}_{4}$ in water was used for analysis and purification using a gradient of $0-50 \%$ over 46 min. Following purification, excess $\mathrm{LiClO}_{4}$ salts were removed using NAP-25 sephadex size-exclusion columns. Oligonucleotides were quantitated by UV (extinction coefficients were determined using the IDT OligoAnalyzer tool (www.idtdna.com/analyzer/Applications/OligoAnalyzer). Extinction coefficients for RNA were used for oligonucleotides containing 4'-Ca-OMe-2'-F.

For GalNAc Containing ONs. Either the succinate of the 3'-nucleoside or GalNAc ligand were conjugated to the CPG via long chain alkylamine (lcaa) with $\sim 500 \AA$ pore size, to which oligonucleotide synthesis initiated from. Upon completion of synthesis, oligonucleotides were treated with $0.5 \mathrm{M}$ anhydrous piperidine in acetonitrile $(\mathrm{MeCN})$ for $10 \mathrm{~min}$, then washed thoroughly with anhydrous $\mathrm{MeCN}$, and dried using nitrogen. Oligonucleotides were cleaved from solid support and deprotected using ammonium hydroxide at $30^{\circ} \mathrm{C}$ for $17 \mathrm{~h}$. After filtration through a nylon syringe filter $(0.45 \mu \mathrm{m})$, oligonucleotides were either stored for purification or in the case of RNA, the 2'-hydroxyl was desilylated by treating with Et3 $\mathrm{N} \cdot \mathrm{HF}$ at $60^{\circ} \mathrm{C}$ for $10 \mathrm{~min}$. 
Oligonucleotides were purified using anion-exchange high-performance liquid chromatography (IEX-HPLC) using an appropriate gradient of mobile phase (0.15 M NaCl, 10\% $\mathrm{MeCN}$ and 1.0 $\mathrm{M} \mathrm{NaBr}, 10 \% \mathrm{MeCN}$ ) and desalted using size-exclusion chromatography with water as an eluent. Oligonucleotides were then quantified by measuring the absorbance at $260 \mathrm{~nm}$ using the following extinction coefficients: $(\mathrm{A}=13.86, \mathrm{~T} / \mathrm{U}=7.92, \mathrm{C}=6.57$, and $\mathrm{G}=10.53)$. The identity and purity (>85\%) of modified oligonucleotides were verified by mass spectrometry (Table S4) and analytical anion exchange chromatography, respectively.

Computational Analysis. The QM/MM molecular dynamics simulations were carried out using AMBER $12^{48}$, with SCC-DFTB ${ }^{49}$ being the choice for the ligand (QM region) and ff99SB ${ }^{50}$ force field for the solvent (MM region). All simulations were carried out in water at a temperature of $303 \mathrm{~K}$ and a pressure of $1 \mathrm{~atm}$ according to the protocol we have established for non-natural nucleosides. $^{51}$

Melting Curves $\left(\boldsymbol{T}_{\mathrm{m}}\right)$. Equimolar amounts $(1.5 \mathrm{nmol})$ of complementary sequences were combined and dried. To the resulting pellet was added $10 \mathrm{mM}$ sodium phosphate buffer ( $\mathrm{pH}$ 7.2) containing $100 \mathrm{mM} \mathrm{NaCl}$ and $0.1 \mathrm{mM}$ EDTA $(1 \mathrm{~mL})$. They were then transferred into cold cuvettes in a Varian UV spectrophotometer. The samples were heated to $90{ }^{\circ} \mathrm{C}$ and then cooled to $5{ }^{\circ} \mathrm{C}$. The change in absorbance at $260 \mathrm{~nm}$ was then monitored upon heating from 5 to $90{ }^{\circ} \mathrm{C}$ at a rate of $0.5{ }^{\circ} \mathrm{C} / \mathrm{min}$. The dissociation temperatures were calculated as the midpoint of the transition $\left(T_{1 / 2}\right)$ using the first derivative of the melting curve.

Circular Dichroism (CD). Circular dichroism (CD) studies were performed at $25{ }^{\circ} \mathrm{C}$ on a Chirascan qCD spectropolarimeter using a $1 \mathrm{~mm}$ path length cuvette. Temperature was maintained using the Peltier unit within the instrument. Spectra were recorded from 320-200 nm at a scan rate of $100 \mathrm{~nm} \mathrm{~min}{ }^{-1}$ and a response time of $2.0 \mathrm{~s}$ with three acquisitions recorded for each spectrum. The spectra were corrected by subtraction of the buffer scan. Data were smoothed using the means-movement function within the Chirsascan graphing software. Oligonucleotide solutions for $\mathrm{CD}$ measurements were prepared with $10 \mathrm{mM}$ sodium phosphate buffer (pH 7.2) in a similar manner to that used for UV melting. The concentration of duplex used was $20 \mu \mathrm{M}$.

Stability Towards 3'-Exonucleases (SVPD) and 5'-Exonuclease (Phosphodiesterase II). Modified oligonucleotides were prepared in a final concentration of $0.1 \mathrm{mg} / \mathrm{mL}$ in either $50 \mathrm{mM}$ 
Tris ( $\mathrm{pH} 7.2$ ), $10 \mathrm{mM} \mathrm{MgCl} 2$ or $50 \mathrm{mM}$ sodium acetate ( $\mathrm{pH} 6.5$ ), $10 \mathrm{mM} \mathrm{MgCl}_{2}$ for assessing the stability towards 3 '- or 5'-specific exonucleases, respectively. The exonuclease $(150 \mathrm{mU} / \mathrm{mL}$ SVPD or $500 \mathrm{mU} / \mathrm{mL}$ phosphodiesterase II) was added immediately prior to analysis via IEX HPLC (dionex DNAPac PA200,4x250 mm) using a gradient of 37-52\% mobile phase (1 M $\mathrm{NaBr}, 20 \mathrm{mM}$ sodium phosphate, $\mathrm{pH}$ 11, 15\% MeCN; stationary phase: $20 \mathrm{mM}$ sodium phosphate, $15 \% \mathrm{MeCN}$, pH 11) over $7.5 \mathrm{~min}$ with a flow of $1 \mathrm{~mL} / \mathrm{min}$. Samples were analyzed every hour for $24 \mathrm{~h}$ and kept at ambient temperatures during the experiment. The quantity of full length oligonucleotide was determined as the area under the curve at A260. Percent full length oligonucleotide was calculated by normalizing to the area under the curve at $t=0$. Activity of enzyme was verified for each experiment by including an oligothymidylate with a terminal phosphorothioate linkage (5'-T $\mathrm{T}_{19 \mathrm{ST}}$ or $5^{\prime}-\mathrm{TsT}_{19}$ for $3^{\prime}$ - or $5^{\prime}$-exonuclease activity, respectively). Each aliquot of enzyme was thawed just prior to the experiment. The average half-life of the corresponding control sequence is $3.1 \mathrm{~h} \pm 0.7$ towards SVPD and $6.3 \mathrm{~h} \pm 0$ towards phosphodiesterase II, and is used to validate the activity of the enzyme for each experimental run. The half-life was determined by fitting to first order kinetics.

RT qPCR for Ttr mRNA Quantification. Primary mouse hepatocytes (PMH) were cultured in Williams E Medium with $10 \%$ fetal bovine serum. Cells were transfected using RNAiMAX reagent according to manufacturer's recommended protocol. Briefly, cells were thawed just prior to transfection, and plated onto 384-well plate with a seed density of $\sim 5000$ cells/well. Preincubated lipid/siRNA complex $(0.1 \mu \mathrm{L}$ RNAiMax, siRNA, in $5 \mu \mathrm{L}$ Opti-MEM for 15 min) was added to a 384-well collagen-coated plate (BioCoat; Corning). Cells were incubated for $20 \mathrm{~h}$ at $37{ }^{\circ} \mathrm{C}$, in an atmosphere of $5 \% \mathrm{CO}_{2}$. Dose responses experiments were done using eight 6-fold serial dilutions ranging from 10 to $0.036 \mathrm{nM}$. Media was then removed and the cells were washed and lysed. RNA was extracted, using Dynabeads mRNA isolation kit according to manufacturer's protocol, then reverse transcribed using ABI high capacity cDNA reverse transcription kit. Quantification was accomplished by real-time PCR, where the cDNA (2 $\mu \mathrm{L})$ was added to a master mix containing $0.5 \mu \mathrm{L}$ mouse GAPDH TaqMan Probe, $0.5 \mu \mathrm{L}$ Ttr TaqMan probes, and $5 \mu \mathrm{L}$ Lightcycler 480 probe master mix per well in a 384-well 50 plates. Real-time PCR was done in an ABI 7900HT RT-PCR system using the $\Delta \Delta C t$ (RQ) assay. Each duplex and concentration was tested in four biological replicates. To calculate relative fold change, real time data were analyzed using the $\Delta \Delta \mathrm{Ct}$ method and normalized to assays 
performed with cells transfected with $10 \mathrm{nM}$ non-specific siRNA. IC50 values were calculated using a 4-parameter fit model using XLFit.

RNA Octamer Crystallization. Crystals of RNA 8-mer oligonucleotides containing 2'-F-4'- $\alpha$ OMe $U$ were grown by the hanging-drop vapor diffusion technique using the Nucleic Acid Miniscreen (Hampton Research, Aliso Viejo, CA). ${ }^{52}$ Crystals were obtained from drops $(0.6 \mu \mathrm{L})$ containing oligonucleotide $(0.5 \mathrm{mM})$, sodium cacodylate $(20 \mathrm{mM}, \mathrm{pH} 6.6)$, sodium chloride (6 $\mathrm{mM})$, potassium chloride $(40 \mathrm{mM})$, hexamine cobalt(III) chloride $(10 \mathrm{mM})$, and 2-methyl-2,4pentanediol (MPD; 5\% (v/v)) that were equilibrated against a reservoir of MPD (70 $\mu \mathrm{L}, 40 \%)$. All crystals were mounted without further cryo-protection and flash-cooled in liquid nitrogen.

X-ray data collection, phasing and refinement. Diffraction data were collected on the 21-ID-G beam line of the Life Sciences Collaborative Access Team (LS-CAT) at the Advanced Photon Source (APS), located at Argonne National Laboratory (Argonne, IL). Crystals were maintained at $100 \mathrm{~K}$ during data collection using a MARCCD 300 detector. Diffraction data were integrated, scaled and merged with HKL2000. ${ }^{53}$ A summary of selected crystal data and data collection parameters is provided in Table 3. The structure was phased by molecular replacement using the program PHASER. ${ }^{54}$ The resulting experimental electron density maps allowed visualization of all 32 nucleotides in the asymmetric unit of the unit cell. Building of the models was performed using the program COOT. ${ }^{55}$ Refinements were carried out using the PHENIX package. ${ }^{56,57}$ The modified residues were built into the electron density and refinement continued with a dictionary created using PRODRG. ${ }^{58}$ Ions and water molecules were added on the basis of Fourier $2 \mathrm{~F}_{o}-\mathrm{F}_{c}$ sum and $\mathrm{F}_{o}-\mathrm{F}_{c}$ difference electron density maps, and accepted on the basis of standard distance and B-factor criteria. Final refinements were carried out using anisotropic temperature factors for all nucleic acid atoms and the final refinement parameters and deviations from ideal geometries are listed in Table 3.

Table 3. Crystal data, data collection and refinement parameters.

Oligonucleotide

\begin{tabular}{lc}
\hline Sequence & $5^{\prime}-\mathrm{r}(\mathrm{CGAA})-\mathbf{X}-(\mathrm{UGC})-3^{\prime}$ \\
Modified nucleotide $(\mathbf{X})$ & $2^{\prime}-\mathrm{F}-4^{\prime}-\alpha-\mathrm{OMe} \mathrm{U}$ \\
Space group & $P 4_{3} 2_{1} 2$
\end{tabular}


Unit cell constants: $\mathrm{a}=\mathrm{b}, \mathrm{c}[\AA]$

Unit cell constants: $\alpha, \beta, \gamma\left[^{\circ}\right]$

Resolution $[\AA]$

Outer shell $[\AA]$ (Data Collection)

Outer shell $[\AA]$ (Refinement)

No. of unique reflections

Completeness (outer shell) [\%]

Wilson B-factor $\left[\AA^{2}\right]$

R-linear (outer shell) [\%]

Rmeas (outer shell) [\%]

Rpim (outer shell) [\%]

$\mathrm{I} / \sigma(\mathrm{I})$ (outer shell) [\%]

R-work (outer shell)

R-free (outer shell)

No. of RNA atoms

No. of waters/ions

R.m.s. deviations bonds $[\AA]$

R.m.s. deviations angles $\left[{ }^{\circ}\right]$

Avg. B-factor $\left[\AA^{2}\right]$

Avg. B-factor, RNA atoms $\left[\AA^{2}\right]$

Avg. B-factor, solvent/ions $\left[\AA^{2}\right]$

PDB entry code (to be assigned)
$44.39,85.92$

$90.0,90.0,90.0$

1.50

1.53-1.50

$1.55-1.50$

14,409

98.8 (97.6)

17.95

$0.067(0.795)$

$0.072(0.857)$

$0.027(0.317)$

21.05(2.73)

$0.186(0.245)$

$0.242(0.321)$

676

137, $1 \mathrm{Co}(\mathrm{III})$ hexamine

0.009

1.8

25.6

23.1

37.6 / 39.9

5VR4

\section{Acknowledgements.}

Financial support was provided by Natural Sciences and Engineering Research Council of Canada (M.J.D. and N.M.), the McGill CIHR Drug Development Training Program (E.M.A. and S.M.M.), and a CGS-M NSERC Scholarship (E.M.A). Generous computational resources were provided by Calcul Québec, Compute Canada and McGill University's High Performance Computing Centre on the Guillimin supercomputer (N.M.). This paper is dedicated to Prof. Kelvin K. Ogilvie on the occasion of his $75^{\text {th }}$ anniversary. 


\section{Supporting Information Available.}

${ }^{1} \mathrm{H},{ }^{13} \mathrm{C},{ }^{19} \mathrm{~F},{ }^{31} \mathrm{P}$, and $2 \mathrm{D}$ NMR spectra for all characterized compounds. Additional $T_{\mathrm{m}}$ data, siRNA assay data (luciferase), half-life of terminally modified oligonucleotides in presence of exonuclease, CD curves, and mass analysis of reported oligonucleotides. The Supporting Information is available free of charge on the ACS Publications website.

\section{References.}

(1) Deng, Y.; Wang, C. C.; Choy, K. W.; Du, Q.; Chen, J.; Wang, Q.; Li, L.; Chung, T. K.; Tang, T. Gene 2014, 538, 217.

(2) Joshi, B. H.; Pachchigar, K. P. Biotechnol. Genet. Eng. Rev. 2014, 30, 1.

(3) Lieberman, J.; Sharp, P. A. JAMA 2015, 313, 1207.

(4) Wu, S. Y.; Lopez-Berestein, G.; Calin, G. A.; Sood, A. K. Sci. Transl. Med. 2014, 6, $240 \mathrm{ps} 7$.

(5) Khvorova, A.; Watts, J. K. Nat. Biotech. 2017, 35, 238.

(6) Deleavey, G. F.; Damha, M. J. Chem. Biol. 2012, 19, 937.

(7) Kawasaki, A. M.; Casper, M. D.; Freier, S. M.; Lesnik, E. A.; Zounes, M. C.; Cummins, L. L.; Gonzalez, C.; Cook, P. D. J. Med. Chem. 1993, 36, 831.

(8) Pallan, P. S.; Greene, E. M.; Jicman, P. A.; Pandey, R. K.; Manoharan, M.; Rozners, E.; Egli, M. Nucleic. Acids. Res. 2011, 39, 3482.

(9) Patra, A.; Paolillo, M.; Charisse, K.; Manoharan, M.; Rozners, E.; Egli, M. Angew. Chem. Int. Ed. Engl. 2012, 51, 11863.

(10) Williams, D. M.; Benseler, F.; Eckstein, F. Biochemistry 1991, 30, 4001.

(11) Layzer, J. M.; McCaffrey, A. P.; Tanner, A. K.; Huang, Z.; Kay, M. A.; Sullenger, B. A. RNA 2004, 10, 766 .

(12) Morrissey, D. V.; Lockridge, J. A.; Shaw, L.; Blanchard, K.; Jensen, K.; Breen, W.; Hartsough, K.; Machemer, L.; Radka, S.; Jadhav, V.; Vaish, N.; Zinnen, S.; Vargeese, C.; 
Bowman, K.; Shaffer, C. S.; Jeffs, L. B.; Judge, A.; MacLachlan, I.; Polisky, B. Nat. Biotechnol. 2005, 23, 1002.

(13) Deleavey, G. F.; Watts, J. K.; Alain, T.; Robert, F.; Kalota, A.; Aishwarya, V.; Pelletier, J.; Gewirtz, A. M.; Sonenberg, N.; Damha, M. J. Nucleic Acids Res. 2010, 38, 4547.

(14) Manoharan, M.; Akinc, A.; Pandey, R. K.; Qin, J.; Hadwiger, P.; John, M.; Mills, K.; Charisse, K.; Maier, M. A.; Nechev, L.; Greene, E. M.; Pallan, P. S.; Rozners, E.; Rajeev, K. G.; Egli, M. Angew. Chem. Int. Ed. Engl. 2011, 50, 2284.

(15) Allerson, C. R.; Sioufi, N.; Jarres, R.; Prakash, T. P.; Naik, N.; Berdeja, A.; Wanders, L.; Griffey, R. H.; Swayze, E. E.; Bhat, B. J. Med. Chem. 2005, 48, 901.

(16) Martínez-Montero, S.; Deleavey, G. F.; Kulkarni, A.; Martín-Pintado, N.; Lindovska, P.; Thomson, M.; González, C.; Götte, M.; Damha, M. J. J. Org. Chem. 2014, 79, 5627.

(17) Jenkins, I. D.; Verheyden, J. P.; Moffatt, J. G. J. Am. Chem. Soc. 1976, 98, 3346.

(18) Owen, G. R.; Verheyden, J. P.; Moffatt, J. G. J. Org. Chem. 1976, 41, 3010.

(19) Lee, S.; Uttamapinant, C.; Verdine, G. L. Org. Lett. 2007, 9, 5007.

(20) Verheyden, J. P.; Jenkins, I. D.; Owen, G. R.; Dimitrijevich, S. D.; Richards, C. M.; Srivastava, P. C.; Le-Hong, N.; Moffatt, J. G. Ann. N. Y. Acad. Sci. 1975, 255, 151.

(21) Liboska, R.; Snášel, J.; Barvík, I.; Buděšínský, M.; Pohl, R.; Točík, Z.; Páv, O.; Rejman, D.; Novák, P.; Rosenberg, I. Org. Biomol. Chem. 2011, 9, 8261.

(22) Petrová, M.; Páv, O.; Buděšínský, M.; Zborníková, E.; Novák, P.; Rosenbergová, Š.; Pačes, O.; Liboska, R.; Dvořáková, I.; Šimák, O.; Rosenberg, I. Org. Lett. 2015, 17, 3426.

(23) Martínez-Montero, S.; Deleavey, G. F.; Dierker-Viik, A.; Lindovska, P.; Ilina, T.; Portella, G.; Orozco, M.; Parniak, M. A.; González, C.; Damha, M. J. J. Org. Chem. 2015, 80, 3083.

(24) Martínez-Montero, S.; Deleavey, G. F.; Martín-Pintado, N.; Fakhoury, J. F.; González, C.; Damha, M. J. ACS Chem. Biol. 2015, 10, 2016.

(25) Wengel, J. Acc. Chem. Res. 1999, 32, 301. 
(26) Obika, S., Nanbu, D., Hari, Y., Andoh, J., Morio, K., Doi, T., and Imanishi, T. Tetrahedron Letters 1998, 39, 5401.

(27) Koshkin, A. A., Singh, S. K., Nielsen, P., Rajwanshi, V. K., Kumar, R., Meldgaard, M., Olsen, C. E., and Wengel, J. Tetrahedron 1998, 54, 3607.

(28) Steffens, R., and Leumann, C. J. J. Am. Chem. Soc. 1999, 121, 3249.

(29) Terrazas, M.; Ocampo, S. M.; Perales, J. C.; Marquez, V. E.; Eritja, R. ChemBioChem 2011, 12, 1056.

(30) Marquez, V. E.; Siddiqui, M. A.; Ezzitouni, A.; Russ, P.; Wang, J.; Wagner, R. W.; Matteucci, M. D. J. Med. Chem. 1996, 39, 3739.

(31) Wang, G.; Gunic, E.; Girardet, J.-L.; Stoisavljevic, V. Bioorg. Med. Chem. Lett. 1999, 9, 1147.

(32) Wang, G.; Deval, J.; Hong, J.; Dyatkina, N.; Prhavc, M.; Taylor, J.; Fung, A.; Jin, Z.; Stevens, S. K.; Serebryany, V. J. Med. Chem. 2015, 58, 1862.

(33) Verheyden, J. P.; Moffatt, J. G. J. Am. Chem. Soc. 1975, 97, 4386.

(34) Maag, H.; Rydzewski, R. M.; McRoberts, M. J.; Crawford-Ruth, D.; Verheyden, J. P.; Prisbe, E. J. J. Med. Chem. 1992, 35, 1440.

(35) Beaucage, S.; Caruthers, M. Tetrahedron Lett. 1981, 22, 1859.

(36) Tong, W.; Agback, P.; Chattopadhyaya, J. Acta Chem. Scand. 1993, 47, 145.

(37) Damha, M. J.; Ogilvie, K. K. Biochemistry 1988, 27, 6403.

(38) Watts, J. K.; Sadalapure, K.; Choubdar, N.; Pinto, B. M.; Damha, M. J. J. Org. Chem. 2006, 71, 921.

(39) Islam, S. M.; Richards, M. R.; Taha, H. A.; Byrns, S. C.; Lowary, T. L.; Roy, P.-N. J. Chem. Theory Comput. 2011, 7, 2989.

(40) Islam, S. M.; Roy, P.-N. J. Chem. Theory Comput. 2012, 8, 2412.

(41) Blandin, M.; Son, T.-D.; Catlin, J. C.; Guschlbauer, W. Biochim. Biophys. Acta - Nucleic Acids and Protein Synthesis 1974, 361, 249. 
(42) Damha, M. J.; Ogilvie, K. K. In Protocols for Oligonucleotides and Analogs: Synthesis and Properties; Agrawal, S., Ed.; Humana Press: Totowa, NJ, 1993, p 81.

(43) Martin-Pintado, N.; Deleavey, G. F.; Portella, G.; Campos-Olivas, R.; Orozco, M.; Damha, M. J.; González, C. Angew. Chem. Int. Ed. 2013, 52, 12065.

(44) Kel'in, A. V.; Zlatev, I.; Harp, J.; Jayaraman, M.; Bisbe, A.; O'Shea, J.; Taneja, N.; Manoharan, R. M.; Khan, S.; Charisse, K. J. Org. Chem. 2016, 81, 2261.

(45) Pallan, P. S.; Allerson, C. R.; Berdeja, A.; Seth, P. P.; Swayze, E. E.; Prakash, T. P.; Egli, M. Chem. Commun. 2012, 48, 8195.

(46) Nair, J. K.; Willoughby, J. L.; Chan, A.; Charisse, K.; Alam, M. R.; Wang, Q.; Hoekstra, M.; Kandasamy, P.; Kel'in, A. V.; Milstein, S.; Taneja, N.; O'Shea, J.; Shaikh, S.; Zhang, L.; van der Sluis, R. J.; Jung, M. E.; Akinc, A.; Hutabarat, R.; Kuchimanchi, S.; Fitzgerald, K.; Zimmermann, T.; van Berkel, T. J.; Maier, M. A.; Rajeev, K. G.; Manoharan, M. J. Am. Chem. Soc. 2014, 136, 16958.

(47) Kypr, J.; Kejnovská, I.; Renčiuk, D.; Vorlíčková, M. Nucleic Acids Res. 2009, 37, 1713.

(48) Case, D.; Darden, T.; Cheatham III, T.; Simmerling, C.; Wang, J.; Duke, R.; Luo, R.; Walker, R.; Zhang, W.; Merz, K. University of California: San Francisco 2012.

(49) Elstner, M.; Porezag, D.; Jungnickel, G.; Elsner, J.; Haugk, M.; Frauenheim, T.; Suhai, S.; Seifert, G. Phys. Rev. B. 1998, 58.

(50) Lindorff-Larsen, K.; Piana, S.; Palmo, K.; Maragakis, P.; Klepeis, J. L.; Dror, R. O.; Shaw, D. E. Proteins: Struct., Funct., Bioinf. 2010, 78, 1950.

(51) Burai Patrascu, M.; Malek-Adamian, E.; Damha, M. J.; Moitessier, N. In Press, 2017.

(52) Jancarik, J.; Kim, S. H. J. Appl. Cryst. 1991, 24, 409-411.

(53) Otwinowski, Z.; Minor, W. Meth. Enzymol. 1997, 276, 307-326.

(54) McCoy, A. J.; Grosse-Kunstleve, R. W.; Adams, P. D.; Winn, M. D.; Storoni, L. C.,; Read, R. J. J. Appl. Crystallogr. 2007, 40, 658-674.

(55) Emsley, P.; Cowtan, K. Acta Cryst. D 2004, 60, 2126-2132. 
(56) Adams, P. D.; Afonine, P. V.,; Bunkoczi, G.; Chen, V. B.; Davis, I. W.; Echols, N.; Headd, J. J.; Hung, L. W.; Kapral, G. J.; Grosse-Kunstleve, R. W.; McCoy, A. J.; Moriarty, N. W.; Oeffner, R.; Read, R. J.; Richardson, D. C.; Richardson, J. S.; Terwilliger, T. C.; Zwart, P. Acta Cryst. D 2010, 66,, 213-221.

(57) Afonine, P. V.; Grosse-Kunstleve, R. W.; Echols, N.; Headd, J. J.; Moriarty, N. W.; Mustyakimov, M.; Terwilliger, T. C.; Urzhumtsev, A.; Zwart, P. H.; Adams, P. D. Acta Cryst. D 2012, 68, 352-367.

(58) Schüttelkopf, A. W; van Aalten, D. M. F. Acta Cryst. D 2004, 60, 1355-1363. 